\title{
Zapis procesów sedymentacji fluwialnej i biogenicznej w osadach dna Doliny Dolnej Wisły
}

\author{
Record of fluvial and biogenic sedimentation processes in sediments \\ of the Lower Vistula Valley floor
}

\section{Jarosław Kordowski ${ }^{1}$, Wojciech Gamrat ${ }^{2}$, Piotr Gierszewski', Katarzyna Kubiak-Wójcicka ${ }^{3}$, Jacek B. Szmańda ${ }^{4}$, Sebastian Tyszkowski ${ }^{1}$, Adam Solarczyk ${ }^{3}$}

${ }^{1}$ Instytut Geografii i Przestrzennego Zagospodarowania, Polska Akademia Nauk, Toruń, jarek@geopan.torun.pl

${ }^{2}$ Katedra Geomorfologii i Paleogeografii Czwartorzędu, Uniwersytet Mikołaja Kopernika, Toruń

${ }^{3}$ Katedra Hydrologii i Gospodarki Wodnej, Uniwersytet Mikołaja Kopernika, Toruń

${ }^{4}$ Instytut Geografii, Uniwersytet Pedagogiczny im. KEN, Kraków

Zarys treści: W artykule przedstawiono przegląd osadów powodziowych i biogenicznych zdeponowanych w dnie Doliny Dolnej Wisły od okolic Górska, w środkowej części Kotliny Toruńskiej, po okolice Grudziądza. Omówiono piaszczyste osady powodziowe, osady basenów popowodziowych i mineralne osady jeziorzysk dolinnych. Dokonano analizy podstawowych własności utworów biogenicznych i ich interpretacji genetycznej. Omówiono też wyniki badań nad rekonstrukcją układu koryta Wisły w ciągu ostatnich 200 lat w Kotlinie Grudziądzkiej i Basenie Unisławskim oraz problem powolnego zamulania starorzeczy powstałych przed regulacją i po regulacji hydrotechnicznej w końcu XIX w. Wyjaśniono kwestię gradientu zawartości węglanowej materii rozpuszczonej w dnie doliny i jego wpływ na sedymentację osadów. Zwrócono uwagę na podobieństwa i różnice w transporcie materii rozpuszczonej i zawieszonej między korytem Wisły i starorzeczami na przykładzie starorzecza Starej Wisły i koryta Wisły w Bratwinie.

Słowa kluczowe: równina zalewowa, zamulanie starorzeczy, Dolina Dolnej Wisły

Abstract: The paper is a review of flood and biogenic sediments which have been deposited on the Lower Vistula Valley floor from the vicinity of Górsk to Grudziądz town. Sandy flood sediments, flood basin sediments and mineral infillings of former back swamps are described. Biogenic sediments are also discussed and genetically interpreted. The results of the Vistula channel reconstruction in Grudziądz Basin and Unisław Basin in the last 200 years are also presented. The reconstruction is strongly linked with the problem of relatively slow siltation of oxbows after the hydrotechnical regulation at the end of XIX-th century. The question of the carbonates gradient in floodplain sediments is also explained. The differences and similarities of the dissolved and suspended matter transport between the main channel and fluvial lake is shown on the example of the oxbow lake and Vistula river channel in Bratwin.

Key words: floodplain, silting of oxbows, Lower Vistula Valley

\section{Wstęp}

Rozwój równin zalewowych dolin rzecznych na obszarze młodoglacjalnym w dużej mierze uwarunkowany jest pierwotną genezą obniżeń włączanych przez rzekę w system fluwialny. Szczególnie widoczne jest to w przypadku Doliny Dolnej Wisły oraz dolin jej dopływów (Andrzejewski 1994, Błaszkiewicz 1998, 2005), gdzie od kilkudziesięciu lat zauważa się istotny wpływ morfogenezy glacjalnej na przebieg procesów fluwialnych (Drozdowski 1974, 1979, 1982, Falkowski 1980, 1990, Brykczyński 1986, Kordowski 2013).

Równina zalewowa to obszar w pobliżu koryta rzecznego, zalewany co najmniej raz w pewnym okresie (Wolman, Leopold 1957). Pod względem genetycznym skła- 
da się ona $\mathrm{z}$ aluwialnych form rzeźby odpowiadających współczesnym warunkom hydrologicznym rzeki (Nanson, Croke 1992). Według Makkavejeva i Čal’ova (1986), równina zalewowa to część dna doliny rzecznej zatapiana okresowymi powodziami, powstała w wyniku akumulacyjno-erozyjnej działalności rzeki. Proces formowania równiny zalewowej polega na stałej wymianie osadu między równiną i korytem rzecznym. W niniejszej pracy przy wydzieleniu równiny zalewowej posłużono się kryterium litologicznym. Stanowi ono, że równina zalewowa to obszar, gdzie deponowane są współcześnie osady powodziowe, lecz nie jest to cały obszar okresowo zalewany przez wody powodziowe. Ma to swoje uzasadnienie w tym, że wody, które wnikają w głąb doliny z dala od koryta rzecznego, mają już znikomą siłę erozyjną i pozbawione są większości osadu zawieszonego, nie mają więc istotnego znaczenia jako czynnik przekształcenia rzeźby i nie biorą udziału w sedymentacji aluwiów. W miejscach tych zaczyna najczęściej dominować czynnik biologiczny, przyczyniający się do utworzenia równin biogenicznych. Ściśle rzecz biorąc, w przypadku Doliny Dolnej Wisły rozległe równiny biogeniczne leżące daleko od koryta w poziomie równiny zalewowej nie są jej częścią, ponieważ dominuje tam niefluwialny czynnik morfogenetyczny. Nie dotyczy to oczywiście sytuacji, kiedy w starorzeczu położonym blisko koryta następuje sedentacja torfów lub akumulacja gytii. $\mathrm{Na}$ analizowanym obszarze takich sytuacji nie rozpoznano.

\section{Specyfika obszaru badań, jego rzeźba i poglądy na rozwój paleogeograficzny}

Równiny zalewowe są bardzo popularnym obiektem badań. Formy te różnią się między sobą pod względem wielkości i sposobu wykształcenia. Większość badań dotyczy form rozwiniętych w rzekach małych, średnich lub rzekach o względnie małym przepływie. Wisła jest największą rzeką w zlewisku Morza Bałtyckiego mającą równinę zalewową, dlatego stopień wykształcenia i wielkość form powodziowych w jej dolnym biegu nie mają tu sobie równych.

Mady rzeczne na obszarze Polski stanowią około 5\% jej powierzchni (Prusinkiewicz, Bednarek 1991), dlatego, ze względu na duży zasięg ich występowania, można mówić o specyfice i niepowtarzalności dna Doliny Dolnej Wisły. Procesy morfogenetyczne związane $\mathrm{z}$ powodziami mają największe natężenie i zasięg w dolnych odcinkach dolin, zwłaszcza dolin dużych (Bloom 1982), gdzie dodatkowo obserwowane są powodzie zatorowe (Grześ 1985, 1991).

Na podstawie dotychczasowych badań uważa się, że dolina Wisły na omawianym odcinku jest formą erozyjną, złożoną z systemu 11 teras (ryc. 1). System ten nawiązuje do teras rozpoznanych na sandrze i w dolinie Brdy (Galon 1953) oraz w dolinach wielu dopływów Wisły (Niewiarowski 1968, Andrzejewski 1994). Według Galona (1961) w poziomach teras XI-X miał odbywać się przepływ wód roztopowych sandrem na południe, zaś w poziomach IXVI miała następować bifurkacja wód Wisły w okolicy Bydgoszczy. Część wód kierowała się na północ przez przełom fordoński, część na zachód do Pradoliny Noteci-Warty. Terasy niższe od VI miały być związane wyłącznie z odpływem w kierunku północnym (Galon 1961). Ostatnio do tego systemu pewne modyfikacje wprowadził Weckwerth (2006), który rozdzielił terasę VI na poziom wyższy (VIa) i niższy (VIb). Poziom VIa związany był, według niego, zarówno $\mathrm{z}$ odpływem $\mathrm{w}$ kierunku północnym, jak i zachodnim, natomiast poziom VIb miał być związany już tylko z odpływem w kierunku północnym. Okres bifurkacji, zdaniem tego autora, był krótszy niż to zakładał Galon (1961) i mógł odbywać się w poziomach teras VIII-VIa. Zagadnienie to jest jednak nadal problematyczne i wymaga dalszych badań.

Badania Berglunda i Drozdowskiego (1976) oraz Niewiarowskiego (1987) i Tomczak (1982, 1987) wykazały, że wszystkie terasy nadzalewowe są starsze od allerødu. Cechą charakterystyczną doliny Wisły poniżej Bydgoszczy jest brak ciągłości tych teras. W Kotlinie Grudziądzkiej stwierdzonych zostało przez Drozdowskiego (1974) dziewięć teras, a w Basenie Unisławskim pięć (Niewiarowski 1987). W Kotlinie Toruńskiej Tomczak (1982, 1987) wydziela cztery terasy (II, IV, VI, IX), nie licząc równiny zalewowej. Według Weckwertha (2010) w Kotlinie Toruńskiej istnieje jedenaście teras sandrowych, pradolinnych i rzecznych Wisły oraz nowo wydzielana terasa przejściowa, jak również dwa poziomy sandrowe z czasu subfazy krajeńsko-wąbrzeskiej zlodowacenia wisły. Powyższe różnice w rekonstrukcjach systemów terasowych Doliny Dolnej Wisły stwarzają wiele problemów interpretacji paleogeograficznego rozwoju jej rzeźby. Jak dotąd nie ma całkowitej pewności, czy korelacja teras w tych trzech odcinkach doliny jest poprawna. Wyjście z tej sytuacji zaproponował Drozdowski (1974), sugerując, że w rozwoju doliny Wisły duży udział miały bryły martwego lodu. Tezę tę potwierdzają ostatnie wyniki kartowania geomorfologicznego w Basenach Unisławskim i Świeckim oraz w Kotlinie Grudziądzkiej (Kordowski 2001, 2005, 2013).

Badania geomorfologiczne równiny zalewowej w Dolinie Dolnej Wisły zostały zapoczątkowane przez Galona (1934), który wydzielił jej dwa poziomy morfologiczne. Poziom wyższy położony jest 3-5 m ponad średnim poziomem rzeki, natomiast poziom niższy $2-3 \mathrm{~m}$. Na obszarze byłego zaboru pruskiego uległ on przekształceniu w wyniku regulacji rzeki przeprowadzonej w końcu XIX w. (Babiński 1984), dzięki czemu zasługuje na miano poziomu antropogenicznego. Klasyfikację poziomów zalewowych Wisły w Basenie Unisławskim wzbogacił Niewiarowski (1987), który podzielił wyższy stopień na poziomy B2 i B1. Poziomy te nie mają w większości przypadków wyraźnej granicy morfologicznej, różnią się natomiast miąższością osadów powodziowych. Miąższość osadów pozakorytowych na poziomie B2 wynosi około $2 \mathrm{~m}$, zaś na poziomie $\mathrm{B} 1$ oscyluje wokół $0,5 \mathrm{~m}$. Badania autorów wykazały, że schemat stworzony przez Niewiarowskiego 
(1987) przenieść można na cały obszar dna doliny Wisły między Toruniem i Grudziądzem (ryc. 1). W celu zachowania konsekwencji terminologicznej dodano oznaczenie B3 dla poziomu ,antropogenicznego".
Wraz z rozwojem badań geologicznych i geomorfologicznych w Dolinie Dolnej Wisły starano się odtworzyć ewolucję stylu rozwinięcia koryta rzecznego na podstawie analizy aluwiów w obrębie współczesnego dna doliny.

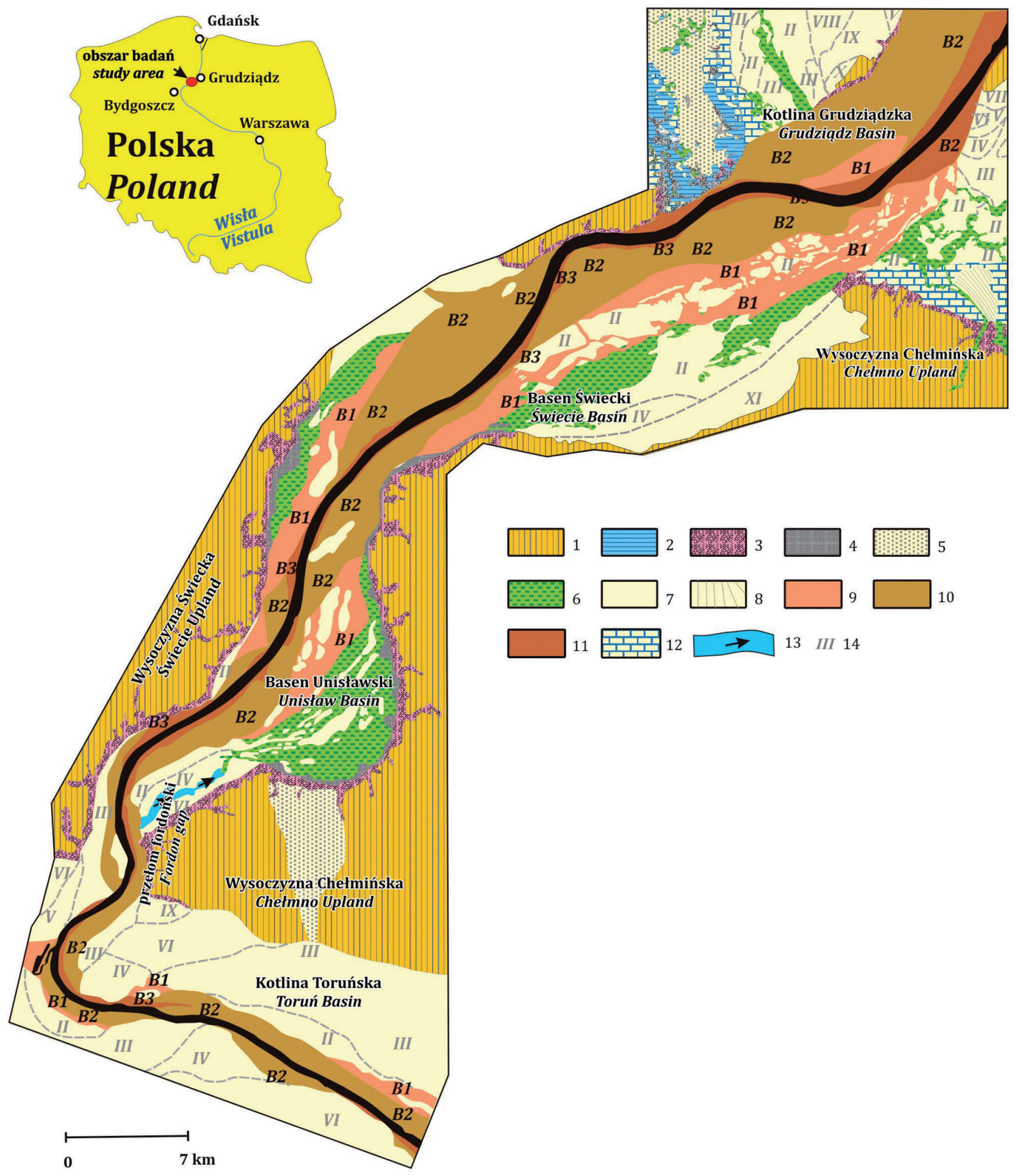

Ryc. 1. Szkic geomorfologiczny doliny Wisły między Górskiem i Grudziądzem

1 - wysoczyzna morenowa, 2 - dna zastoisk, 3 - długie stoki, 4 - strefy akumulacji deluwiów, 5 - równiny sandrowe, 6 - równiny biogeniczne, 7 - terasy fluwioglacjalne i fluwialne, 8 - stożki napływowe, poziomy równiny zalewowej: 9 - B1, 10 - B2, 11 - B3, 12 - kemowe terasy późnoglacjalne z dużym udziałem osadów spływowych, częściowo przewiane, 13 - późnoglacjalne koryto Wisły w zaadaptowanej rynnie subglacjalnej, 14 - numery teras

Fig. 1. Geomorphological sketch of the Vistula valley between Górsk and Grudziądz

1 - till plain, 2 - bottoms of ice dammed lakes, 3 - long slopes, 4 - colluvial accumulation, 5 - outwash plains, 6 - biogenic plains, 7 - fluvioglacial and fluvial terraces, 8 - proluvial fans, floodplain levels: 9 - B1, 10 - B2, 11 - B3, 12 - Late Glacial kame terraces, partly windblown, 13 - Late Glacial Vistula channel in an adopted subglacial channel, 14 - terraces numbers 
Przeciętna miąższość wypełnienia aluwialnego na analizowanym obszarze wynosi około $10 \mathrm{~m}$, co odpowiada największym przegłębieniom w obrębie współczesnego koryta Wisły (Babiński 1981). Dolną serię osadów równiny zalewowej budują piaski gruboziarniste i żwiry, które według Drozdowskiego (1982) są osadami rzeki roztokowej. Górną część aluwiów zajmują piaski drobnoziarniste, piaski mułkowate, mułki piaszczyste i ilaste oraz iły. Według Falkowskiego (1971) i Drozdowskiego (1982) osady te związane są z działalnością rzeki meandrującej. Przejście od rzeki o roztokowym rozwinięciu koryta do rzeki meandrującej miało nastąpić w okresie atlantyckim, kiedy poziom wody w Bałtyku uległ stabilizacji (Falkowski 1971, Drozdowski 1982). Ponowne przejście do systemu roztokowego miało zaznaczyć się kilkaset lat temu, w wyniku odlesienia dorzecza Wisły (Falkowski 1971, Drozdowski 1982).

Strop aluwiów równiny zalewowej tworzą osady pozakorytowe. Wyniki datowania radiowęglowego torfów wypełniających starorzecza w Kotlinie Toruńskiej, podścielających utwory powodziowe, wskazują, że depozycja mad rzecznych rozpoczęła się tu co najmniej przed około 1900 lat BP, a proces zatorfiania opuszczonych koryt został zainicjowany 5400-5500 lat BP (Tomczak 1987). Wyniki badań Niewiarowskiego (1987) w Base- nie Unisławskim dowodzą wcześniejszej depozycji mad rzecznych na poziomie B1, co najmniej od 3000-4000 lat wstecz. Z badań Biernackiego (1968, 1975), przeprowadzonych w rejonie Warszawy, wynika, że depozycja mad zaczęła się tam dopiero 4500 lat temu i miała dwufazowy charakter. Między 4500 i 1500 lat temu nastąpiła akumulacja mady bardziej ilastej (dolna seria mad), a w ciągu ostatnich 600 lat doszło do akumulacji mady bardziej piaszczystej (górna seria mad). W okresie 1500-600 lat temu miała miejsce przerwa w sedymentacji, wyrażająca się rozwojem warstwy gleby kopalnej. Podobne wyniki badań uzyskali Myślińska (1980, 2001) oraz Myślińska i in. (1982) w Dolinie Dolnej Wisły w rejonie Bydgoszczy, gdzie wyróżnione zostały także dwie serie mad. Mada starsza, bardziej ilasta, miała powstać w stadium rzeki meandrującej, zaś mada młodsza, bardziej mułkowata, w środowisku rzeki roztokowej.

Dolina Dolnej Wisły doświadczyła znacznych zmian rzeźby wskutek działalności człowieka. Przed regulacją wykonaną w drugiej połowie XIX w., główne koryto Wisły było szersze niż dzisiaj (ryc. 2), podzielone na kilka ramion bocznych (Koc 1972, Babiński 1984, Kordowski $\mathrm{i}$ in. 2012). Miało wiele cech anastomozującego systemu fluwialnego (Kordowski 2009b). Pruskie zabiegi hydrotechniczne doprowadziły do podziału równiny zalewowej

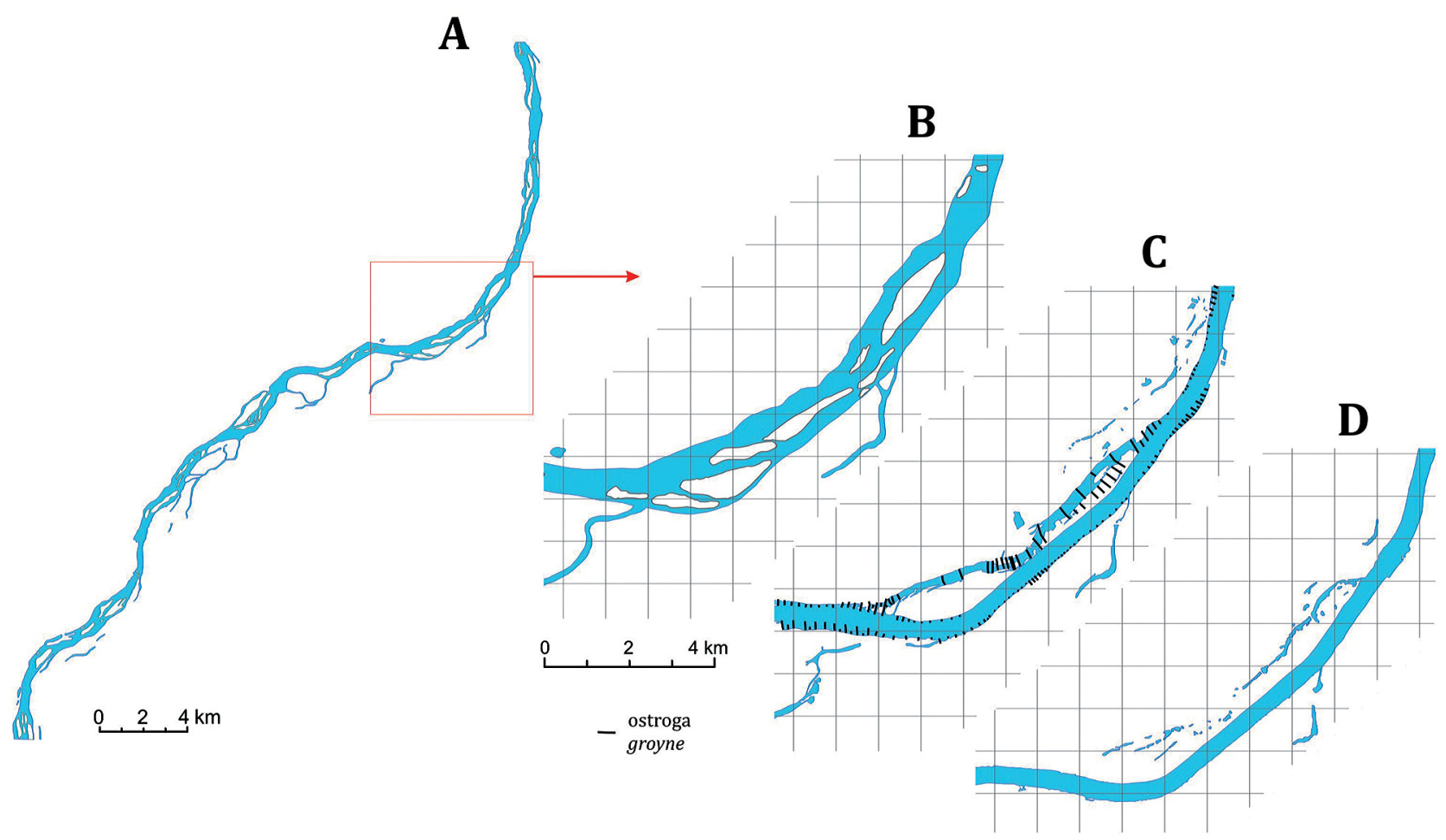

Ryc. 2. Zmiany układu koryta Wisły w czasie XIX i XX w.

A - rekonstrukcja koryta Wisły między Grudziądzem i Borównem w Basenie Unisławskim według map Schröttera z początku XIX w., B - układ koryta Starej Wisły i Wisły w okolicach Bratwina i Dragacza z początku XIX w., C - układ koryta Starej Wisły i Wisły w okolicach Bratwina i Dragacza z początku XX w., D - układ koryta Starej Wisły i Wisły w okolicach Bratwina i Dragacza z początku XXI w.

Fig. 2. Vistula channel changes during XIX-th and XX-th centuries

A - reconstruction of Vistula river channel between Grudziądz and Borówno in Unisław Basin after Schrötter's maps from the beginning of the XIX th century, B - further channel pattern of the Old Vistula and Vistula in the vicinity of Bratwin and Dragacz on the beginning of the XIX-th century, C channel pattern of the Old Vistula and Vistula in the vicinity of Bratwin and Dragacz on the beginning of the XX-th century, D - channel pattern of the Old Vistula and Vistula in the vicinity of Bratwin and Dragacz on the beginning of the XXI-st century 
wałami przeciwpowodziowymi. Koryto Wisły zostało zwężone i pogłębione wskutek erozji, która nastąpiła po zbudowaniu ostróg i przegród kamiennych. W rezultacie do już istniejących jezior starorzeczy dołączyły nowe. Tylko niewielka część z nich uległa całkowitemu wypełnieniu. Zdaniem Babińskiego (1984) proces wypełniania i odcinania drugorzędnych koryt spowodował zwężenie koryta głównego na obszarze byłego zaboru pruskiego o przeciętnie $162 \mathrm{~m}$, ale jedynie $16 \%$ materiału zerodowanego od tego czasu z koryta rzecznego zdeponowane zostało między przegrodami i ostrogami głównie w starych ramionach rzecznych.

\section{Cele i metody pracy}

Celem niniejszego artykułu jest dokonanie przeglądu osadów powodziowych i utworów biogenicznych w dnie Doliny Dolnej Wisły i analiza procesów, jakie prowadzą do ich akumulacji na podstawie wyników badań sedymentologicznych i obserwacji współczesnych procesów korytowych, dokonanych po przejściu fal powodziowych w 1997 i 2010 r. Wykorzystano także obserwacje mobilności materii zawieszonej i rozpuszczonej we współczesnym korycie Wisły i w starorzeczu Starej Wisły w Bratwinie.

Wyniki prezentowanych badań są efektem wieloletnich geologicznych i geomorfologicznych prac kartograficznych prowadzonych w Dolinie Dolnej Wisły na odcinku między Górskiem i Grudziądzem. W przypadku zagadnienia wyhamowanego procesu zamulania starorzeczy po regulacji rzeki z końca XIX w. zwrócono uwagę na uwarunkowania zmienności transportu zawiesiny i materiału rozpuszczonego na podstawie pomiarów prowadzonych co dwa tygodnie od lutego 2011 r. Ilość zawiesiny określono metodą sączkową, a mineralizację na podstawie suchej pozostałości. Mineralizację węglanową oznaczono metodą Scheiblera.

Zastosowane w artykule skróty litologiczno-strukturalne nawiązują do kodu litofacjalnego Zielińskiego (1995): S - piasek, F - mułki i iły, h - warstwowanie horyzontalne, 1 - warstwowanie małokątowe, $\mathrm{m}$ - struktura masywna, $\mathrm{w}$ - laminacja falista, $\mathrm{r}$ - laminacja riplemarkowa, $\mathrm{rt}$ - rytmit, $\mathrm{t}$ - warstwowanie przekątne rynnowe.

\section{Charakterystyka osadów równiny zalewowej i równin biogenicznych}

\section{Osady powodziowe}

Osady równiny zalewowej najogólniej można podzielić na piaszczyste i mułkowo-ilaste, którym odpowiada zróżnicowanie procesów morfogenetycznych. W niniejszym opracowaniu są one omówione jako tło do analizy przestrzennego zasięgu typów osadów powodziowych (ryc. 3-7). Ich cechy strukturalne oraz charakterystyka uziarnienia zostały omówione w pracach Kordowskiego (1999, 2001, 2009a) oraz Szmańdy (2000, 2007). Zależności sposobu sedymentacji na równinie zalewowej od zmiany prędkości wody w korycie rzeki, odległości od koryta, zróżnicowania wysokości równiny, lesistości, spadku, szerokości i prędkości przepływu pozakorytowego, analizowali szeroko Zwoliński (1985), Kalicki (2000), Ludwikowska-Kędzia (2000) i Szmańda (2011).

\section{Osady piaszczyste}

Osady piaszczyste budują zróżnicowany genetycznie inwentarz form fluwialnych. Obejmuje on głównie wały przykorytowe, cienie piaszczyste, stożki aluwialne i wstęgi terasowe (por. Zwoliński 1985). Występowanie tych form i tworzących je piasków na równinie zalewowej Doliny Dolnej Wisły jest nierównomierne (ryc. 4).

Wały przykorytowe definiowane są jako soczewkowate formy obramowujące koryta rzek, powstające w wyniku spowolnienia przepływu wód powodziowych wydostających się poza koryto rzeczne (Reineck, Singh 1986). Rzadko wykształcone są na obu brzegach rzeki jednocześnie (Davies 1983). Ich osady wykazują duże podobieństwo do górnych serii osadów korytowych (Bridge 2003, 2006). Typowy wał przykorytowy zbudowany jest głównie z piasków z przewarstwieniami mułku piaszczystego z dominacją warstwowania horyzontalnego, które ku stropowi przechodzi w małoskalowe warstwowanie przekątne i laminację riplemarkową (Bridge 1984, Szmańda 2006). W osadach wału przykorytowego spotykane są bioturbacje i struktury szczelin $\mathrm{z}$ wysychania. Częste są wypełnienia płytkich kanałów, kontakty erozyjne i rozmycia (Gibling, Rust 1984). Pojedyncze zestawy wymienionych warstwowań mają od kilku do kilkudziesięciu centymetrów miąższości. $Z$ biegiem rzeki grubość ziaren budujących wały przykorytowe zmniejsza się (por. Szmańda 2011). Udział osadów wałów przykorytowych w całości osadów powodziowych dolnej Wisły jest niewielki, ponieważ reprezentują one najprawdopodobniej tylko jedną generację tych form. Odsetek objętości ich osadów w ogólnej objętości osadów powodziowych nie przekracza $2-2,5 \%$. Wały przykorytowe na odcinku doliny Wisły poniżej Fordonu rozwinięte są zaledwie na około $1 / 3$ długości brzegów rzeki (Kordowski 2004). Ich szerokość jest niewielka, bowiem jest to średnio kilkanaście do kilkudziesięciu metrów, wyjątkowo ponad $100 \mathrm{~m}$. Wały przykorytowe Wisły przecięte są licznymi krewasami świadczącymi o obecności wirów horyzontalnych skierowanych od koryta ku równinie zalewowej (por. Bridge 2006). Wymiana materii zawieszonej i wleczonej jest więc mniej utrudniona niż $\mathrm{w}$ rzekach $\mathrm{z}$ dobrze rozwiniętymi wałami przykorytowymi (Bridge 2003, 2006).

Wały przykorytowe Wisły zostały podzielone na inicjalne i rozwinięte. Typowe litofacje inicjalnych wałów przykorytowych w kolejności ich występowania to SFh, FSh, Fm, akcesorycznie Sw, Sp, Sr. Wały inicjalne charakteryzują się rytmiczną przemiennością warstw piaszczystych i mułkowo-ilastych. Obydwa rodzaje warstw 


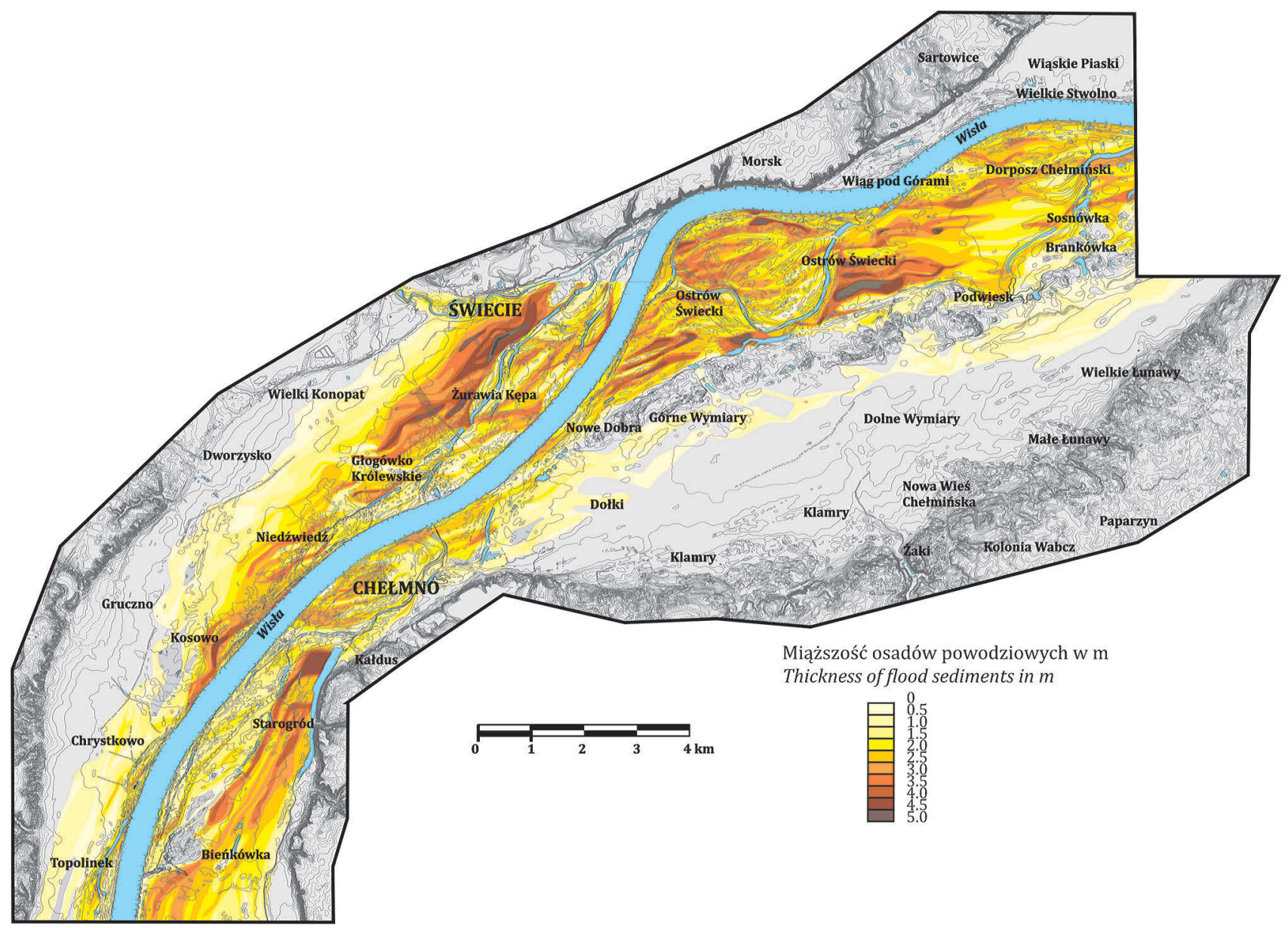

Ryc. 3. Zasięg i miąższość osadów powodziowych na obszarze równiny zalewowej Wisły w okolicy Świecia

Fig. 3. The extent and thickness of flood sediments on the area of the of the Vistula floodplain in the vicinity of Świecie

mają zbliżoną miąższość. W stropie przechodzą zazwyczaj w wały rozwinięte. Warstwy mułkowe są masywne, natomiast warstwy piaszczyste są warstwowane horyzontalnie, równolegle, gdzie układ lamin jest równoległy do powierzchni, na której następuje sedymentacja (Szmańda 2006). Przewarstwienia mułkowe osiągają od kilku milimetrów do kilku centymetrów. Przewarstwienia piaszczyste są nieco bardziej miąższe. Częste są nieregularne wkładki i zdeformowane bryły mułkowe. Spotyka się też rytmiczną laminację piasku z mułkiem o grubości do kilku milimetrów. Ponadto stwierdzono kilkunastocentymetrowe warstwy piasku warstwowanego przekątnie płasko. Obecność niewyraźnego warstwowania falistego wskazuje na przekształcenia w wyniku falowania wód koryta rzeki.

Typowe litofacje rozwiniętych wałów przykorytowych w kolejności występowania to SFrt, FSrt, Sh, Sl, Sm, St. Tworzą je piaski drobnoziarniste ze sporadycznymi wkładkami mułków. W osadach tych dominuje struktura masywna i warstwowanie horyzontalne, częste są także zaburzenia biogenicznie i klasty mułkowe. Spotyka się też warstwowanie rynnowe o głębokości rynienek rzędu 20-30 cm. Powszechne w rozwiniętych wałach przykorytowych są rytmity piaszczysto-mułkowe o grubości lamin do kilku milimetrów, jak również smugi piasku mułkowatego w piasku o dobrym wysortowaniu. W niektórych warstwach piasku masywnego, najczęściej mułkowatego, zdarzają się kilkucentymetrowe soczewki dobrze wysortowanego piasku o warstwowaniu horyzontalnym. Świadczy to zapewne o depozycji na przemarzniętym materiale (por. Wysota i in. 1996). Stosunkowo rzadko występują warstwy o warstwowaniu przekątnie płaskim i o miąższości do $30 \mathrm{~cm}$. W zestawach warstwowania horyzontalnego zdarzają się litofacje o laminacji riplemarkowej. Inwentarz typowych struktur sedymentacyjnych zamykają rytmity piaszczysto-mułkowe o grubości lamin do kilku milimetrów. W osadach rozwiniętych wałów przykorytowych spotkano postsedymentacyjne ugięcia lamin, czasami nawet o kąt ponad $90^{\circ}$. Zjawisko takie następuje w wyniku niewielkiego przesunięcia warstewek po ich przymarznięciu do kry lodowej, wówczas rozszerzający się termicznie lód rozciąga osad.

Typowe litofacje cieni piaszczystych to Sh, Sr, Sl. Tworzą je drobno- i średnioziarniste piaski o laminacji riplemarków wstępujących, nierzadko podścielone warstwą piasków masywnych. Laminacja riplemarków wstępujących ku stropowi przechodzi w warstwowanie horyzontalne (ryc. 8F). Początek depozycji cienia piaszczystego zaznacza się zazwyczaj cienką $(2-3 \mathrm{~cm})$ warstewką piasku średnio- lub gruboziarnistego o warstwowaniu horyzontalnym lub przekątnym małokątowym. Po powodzi w 2010 r. obserwowano cienie o długości ponad $50 \mathrm{~m}$, szerokości około $20 \mathrm{~cm}$ i wysokości najwyżej kil- 


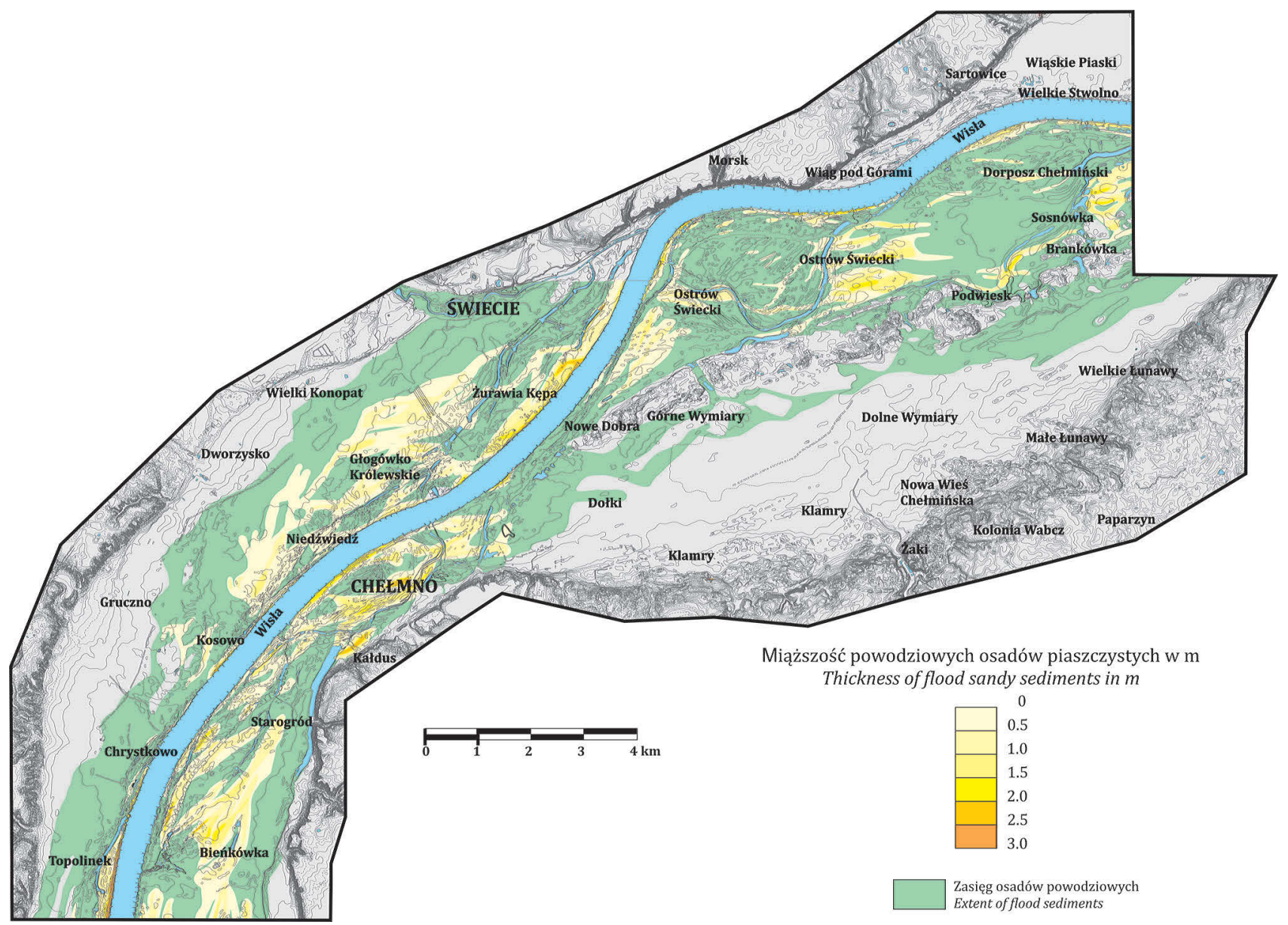

Ryc. 4. Zasięg i miąższość sedymentacji piaszczystych osadów powodziowych na obszarze równiny zalewowej Wisły w okolicy Świecia

Fig. 4. Extent and thickness of sandy flood sediments on the area of the Vistula floodplain in the vicinity of Świecie

kunastu centymetrów. Tworzyły się za pniami drzew, bryłami mułku powstałymi po orce na wiosnę lub za kępami chwastów (ryc. 8A, C).

Wstęgi piaszczyste w literaturze fluwialnej opisywane są jako duże piaszczyste formy powstające poza wałami przykorytowymi (Zwoliński 1985). Mają one różne nazwy (naspy, glify krewasowe, wstęgi terasowe, ang. crevasse splays, flood-plain splays). Formy te powstają, kiedy nadmiar wód powodziowych przelewa się przez wały przykorytowe, deponując na obszarze równiny zalewowej osady gruboziarniste transportowane wcześniej w korycie rzecznym wraz z domieszka rozmytych utworów pozakorytowych (wzbogacenie w mułki, materię humusową, toczeńce itd.) (Happ i in. 1940, Mjøs i in. 1993). Klasyczne glify krewasowe spotyka się na równinach zalewowych rzek meandrujących, zwłaszcza na wklęsłych brzegach meandrów (Davies 1983, Zwoliński 1985). Tworzą się zazwyczaj prostopadle do koryta rzeki bezpośrednio za wałem przykorytowym. Mogą ulegać reaktywacji w kolejnych epizodach powodziowych. Bridge (2003) przyjmuje, że formy te mają długość od kilkuset metrów do nieco ponad kilometra. Są one bardziej gruboziarniste i bardziej miąższe niż osady wałów przykorytowych. Spotyka się w nich liczne drobne koryta krewasowe ze śladami zamierania przepływu wody.
Typowe litofacje wstęg piaszczystych w przypadku dolnej Wisły to Sh, Sm, Sr, SFm, SFr. W przerwach między epizodami sedymentacji wstęg dochodziło do depozycji litofacji Fm, FSm, Sm, SFm, SFrt. Wstęgi piaszczyste w Dolinie Dolnej Wisły tworzą się u wylotu krewas i rozbudowują się zazwyczaj równolegle do koryta rzecznego. Stąd też propozycja, by formy te nazwać wstęgami piaszczystymi, a nie glifami krewasowymi. Ostatnio stwierdzono w Dolinie Dolnej Wisły normalne glify krewasowe, jeden w okolicy Grudziądza w stanie kopalnym (w opracowaniu), drugi w okolicach Płocka (Świniary) po przejściu powodzi z 2010 r. (Gierszewski, Szmańda 2012, Szmańda, Gierszewski 2013).

Baseny popowodziowe, zwane też basenami dekantacyjnymi (Zwoliński 1985), to najniżej leżące fragmenty równiny zalewowej (Reineck, Singh 1986). Funkcjonują jako osadniki, w których deponowane są zawieszone w wodach powodziowych cząstki drobnoziarniste. Ich osady tworzą wydłużone, tabularne lub pryzmatyczne jednostki sedymentacyjne. Obserwuje się w nich warstwowania o skali od milimetrów do centymetrów (Bridge 2003). Jeśli na równinie zalewowej przez dłuższy czas utrzymywały się płytkie zbiorniki wodne, to wśród osadów basenów popowodziowych występują soczewki piasku o laminacji riplemarkowej. Opisywane są rów- 
nież ślady kropel deszczu, szczeliny z wysychania, zwitki błotne, wkładki piasku eolicznego, skamieniałości ślimaków, mięczaków, ślady korzeni czy wtórne poziomy glebowe. Struktury te i osady zostały podzielone na typowe i przetransformowane $\mathrm{w}$ wyniku procesów postsedymentacyjnych o różnym układzie przestrzennym.

Osady typowych basenów popowodziowych w Dolinie Dolnej Wisły, zbudowane $\mathrm{z}$ jednolitych warstw mułków i iłów, są dość rzadkie. Występują one wyłącznie w dystalnych częściach równiny zalewowej i mają strukturę masywną (ryc. 5). Zazwyczaj tworzą dolną partię serii osadów powodziowych. Dość powszechne jest w nich występowanie drobnych muszli ślimaków. Depozycja zawieszonego materiału mułkowo-ilastego ma skomplikowany charakter (Talling i in. 2012). Przy niskich koncentracjach zawiesiny, rzędu setnych procenta, następuje flokulacja zderzających się cząstek. Największe z tak powstałych agregatów mogą opadać $\mathrm{z}$ prędkością piasku. W miarę ubytku wody (np. wskutek parowania), gdy koncentracja mułu osiąga wartości między 0,5 a $2 \%$, w efekcie oddziaływania sił elektrostatycznych między minerałami ilastymi tworzy się kohezyjny, galaretowaty żel. Przy postępującej koncentracji osadu żel ten jest w stanie unieść na swej powierzchni ziarna piasku i przemieszczać się po prawie płaskim stoku, między innymi w wyniku impulsu indukowanego falowaniem w płytkich zbiornikach wodnych (Talling $\mathrm{i}$ in. 2012). Typowe litofacje opisywanych basenów popowodziowych to Fm, bardzo rzadko Fh.

Przetransformowane baseny popowodziowe są spotykane w Dolinie Dolnej Wisły znacznie częściej. Ich typowe litofacje to Fm, FSm, SFm, Sm. Tworzące je mułki charakteryzują się obecnością wkładek piaszczystych, najczęściej o strukturze masywnej. Przewarstwienia te mają miąższość od kilku do kilkunastu centymetrów. Akcesorycznie wykazują one warstwowanie horyzontalne. Zazwyczaj są zaburzone grawitacyjnie w wyniku ciśnienia nadkładu materiału mułkowatego. Nacisk ten przyczynia się do rozerwania i powyginania warstw. Bardzo rzadko w mułku piaszczystym można zauważyć delikatne warstwowanie horyzontalne. W dnach krewas charakterystyczne jest przewarstwianie się mułku o drobniejszym ziarnie z mułkiem o grubszym ziarnie. Warstwy takie mają od kilku do kilkunastu centymetrów miąższości, a całe zestawy takiego warstwowania mogą osiągnąć 1,1 m. W mułkowo-ilastej matriks spotyka się często soczewki piasku. Były one tu zdeponowane prawdopodobnie zimą, jako przemarznięte toczeńce piaszczyste. Makroskopowo jednorodna, mułkowo-ilasta matriks cechuje się domieszką wtórnie wprowadzonego materiału piaszczystego. Jego dostawa mogła nastąpić w wyniku

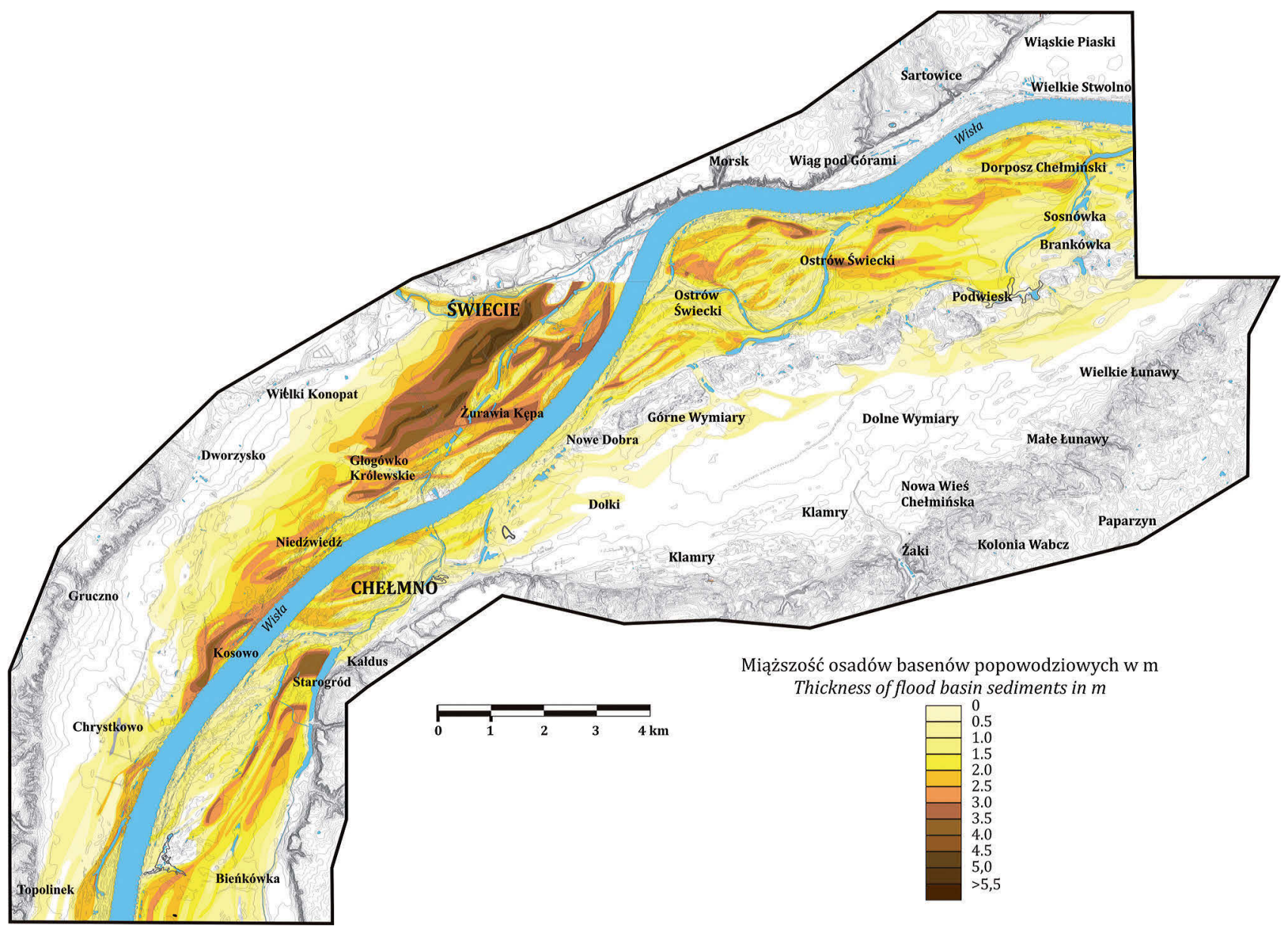

Ryc. 5. Zasięg i miąższość osadów w basenach popowodziowych na obszarze równiny zalewowej Wisły w okolicy Świecia

Fig. 5. Extent and thickness deposits in the flood basins on the area of the Vistula floodplain in the vicinity of Świecie 
rozwiewania wałów przykorytowych i wstęg piaszczystych, jakie następuje późną jesienią, zimą i wiosną. Materiał ten może też pochodzić z wydm lub być efektem depozycji wód powodziowych przemieszczających się po przemarzniętym gruncie.

Drobnoziarnisty, mułkowo-ilasty skład ziarnowy basenów popowodziowych powoduje łatwość powstawania szczelin z wysychania. W szczeliny te dostaje się materiał osadowy z powierzchni terenu. Przy pęcznieniu powstaje z kolei duże ciśnienie powodujące formowanie się powierzchni ścięć (ang. slickensides), czego rezultatem jest przemieszczanie osadu. Mady ilaste wykazują zatem pewne podobieństwo z vertisolami, choć są od nich różne ze względu na brak rzeźby typu gilgai, czyli drobnych zagłębień i wzniesień (rzędu $20 \mathrm{~cm}$ ) na powierzchni gleby, oraz stosunkowo mały udział iłów koloidalnych w budowie profilu glebowego, który powinien wynosić minimum 30\% (Legros 2012).

Transport materiału mułkowego na obszarze równin zalewowych zdaniem Bridge'a (2006) z reguły następuje w wyniku przydennego transportu różnej wielkości okruchów (ang. pellet), a nie w formie zawiesiny. Zjawisko transportu okruchów o średnicy do 6-7 mm obserwowane było w Bratwinie w czerwcu 2010 r. (ryc. 8D). Również Szmańda (2011) wskazuje na to, że osady basenów popowodziowych nie zawsze związane są tylko z piono- wym przyrostem osadów z wytrącania zawiesiny. Nie ulega wątpliwości, że w tym względzie potrzebne są dalsze badania nad ustaleniem ilościowego stosunku depozycji zawiesinowej do depozycji $\mathrm{z}$ trakcji $\mathrm{w}$ czasie powodzi i ich uwarunkowaniami lokalnymi oraz sezonowymi.

Mineralne osady jeziorzysk dolinnych są wypełnieniami opuszczonych koryt rzecznych, ramion bocznych i koryt wód powodziowych, a także licznych zagłębień po martwym lodzie. Typową litofacją mineralnych osadów jeziorzysk dolinnych jest litofacja Fm (w większości ,tłusty" ił koloidalny), bardzo rzadko litofacje FSm, Sm. Osady jeziorzysk dolinnych są reprezentowane przez niebieskie lub szare iły koloidalne (ryc. 5). Są one pozostałością dawnych rozlewisk dolinnych, jakie powstały bezpośrednio przed depozycją typowych osadów powodziowych. Występują one w dystalnych fragmentach równiny zalewowej i naśladują przebieg układu roztokowego koryt na równinie zalewowej, powstałego w późnym glacjale. Ich maksymalna miąższość dochodzi do $3,5 \mathrm{~m}$. Podobne do nich osady ilaste o strukturze masywnej wyścielają dna dawnych równin jeziornych wypełnionych gytią i torfowisk, które powstały także w późnym glacjale. Wśród iłów częste są wkładki brązowej gytii drobnodetrytusowej lub fragmenty gałęzi, muszle ślimaków, fragmenty korzeni i łodyg trzcin.

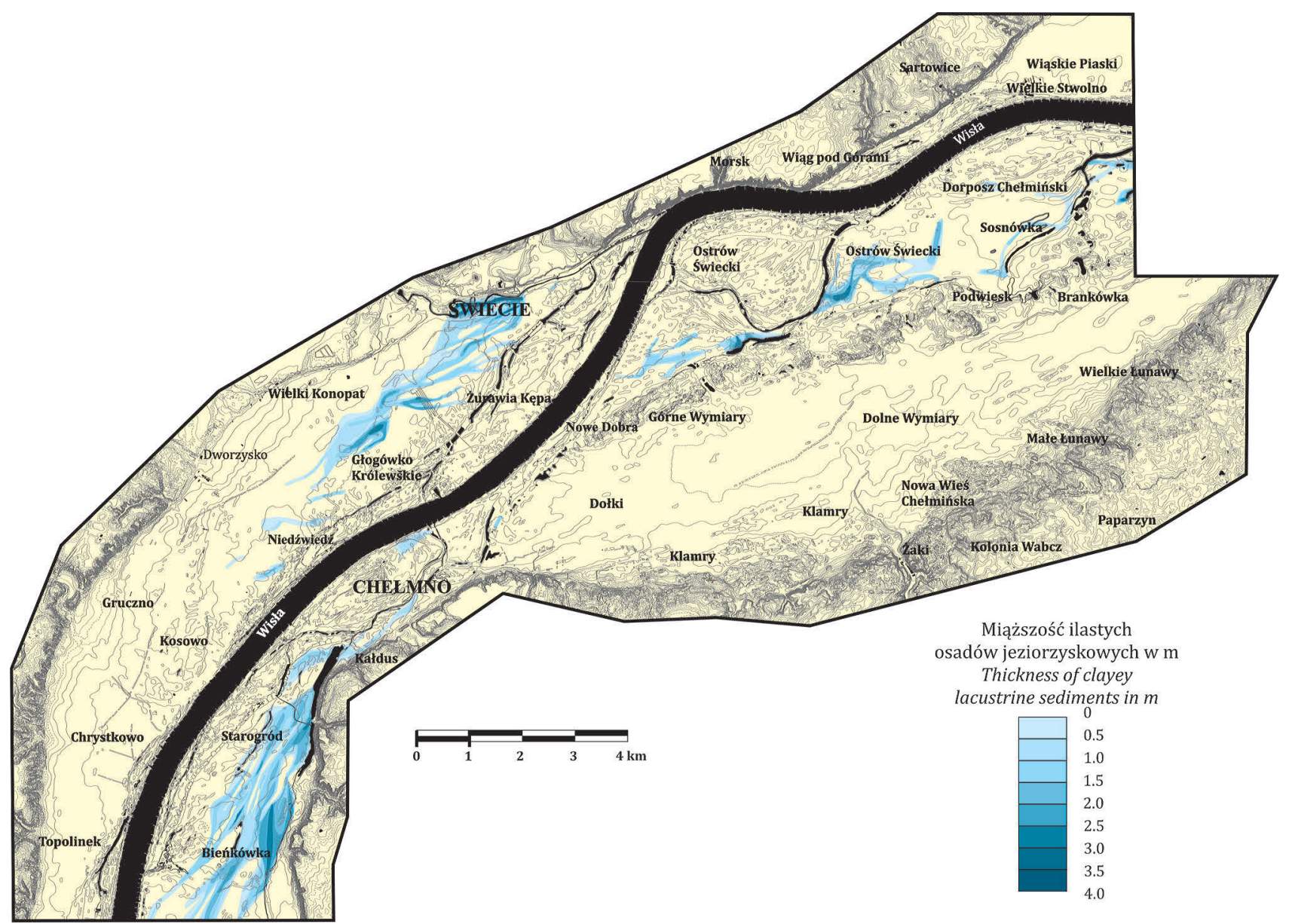

Ryc. 6. Zasięg i miąższość jeziorzyskowych osadów ilastych na obszarze równiny zalewowej Wisły w okolicy Świecia Fig. 6. Extent and thickness of clayey lacustrine deposits on the area of the Vistula floodplain in the vicinity of Świecie 


\section{Osady biogeniczne}

Osady biogeniczne i torfy wypełniające dawne koryta i ramiona rzeczne koncentrują się $\mathrm{z}$ dala od koryta rzeki (ryc. 7). Maksymalna stwierdzona miąższość tego typu osadów wynosi $8 \mathrm{~m}$ w małym wytopisku w okolicy Łoskonia na północ od Bydgoszczy. W Basenie Unisławskim maksymalna miąższość tych osadów osiąga $6,4 \mathrm{~m}$.

Torfy występują w strefach brzegowych oraz sporadycznie $\mathrm{w}$ strefach centralnych dawnych jeziorzysk $\mathrm{w}$ formie redeponowanej, jako cienkie kilkucentymetrowe warstwy. W dolnej części mają one charakter mszysty, ku górze profili przechodząc $\mathrm{w}$ torf ze zwiększonym udziałem turzyc. W zasadzie są bezwęglanowe, chociaż w pojedynczych próbkach zawartość węglanów może dochodzić do kilku procent. Zawartość węglanów wyliczona w 1058 próbkach wynosiła $0,9 \%$, straty prażenia $63,1 \%$, zaś niewęglanowa pozostałość mineralna 36\%. Największa zawartość węglanów notowana jest w torfach na granicy z gytiami węglanowymi, gdzie może dochodzić do 8-12\%. Torfy z doliny Wisły charakteryzują się bardzo wysoką popielnością (blisko 37\%), co spowodowane jest zamulaniem zarówno osadami deluwialnymi, jak i okresowym dopływem wód powodziowych. Wartość ta jest jednak bardzo zmienna. W czystych torfach wskaźnik popielności mieści się między 10 a $20 \%$. Gytie zajmują centralne strefy jeziorzysk, mają dość duży udział węglanu wapnia w swoim składzie, sięgający 30-79\%, nigdzie jednak nie przechodzą w kredę jeziorną. Przeciętna zawartość węglanów wyliczona na podstawie analizy 1943 próbek wynosi 39,9\%, straty prażenia $28,2 \%$, zaś niewęglanowa pozostałość mineralna $-39,9 \%$. W jednym $z$ wierceń spotykano poziomy pożarowe z licznymi węgielkami drzewnymi. Warstwy te mogą osiągać do $30 \mathrm{~cm}$ miąższości. Wahania zawartości węglanów, substancji organicznej i niewęglanowej substancji nieorganicznej wskazują na występowanie wielu cykli sedymentacyjnych, które są efektem zmian poziomu wody. Ku stropowi wielu profili obserwuje się zwiększony udział substancji organicznej i węglanów. Część z nich nadbudowana jest przez cienką warstwę mułków ilastych pochodzenia powodziowego, stąd wniosek, że przed ich sedymentacją $\mathrm{w}$ stropie osadów organicznych zapisał się proces eutrofizacji. O znacznych wahaniach poziomu wody na obszarze bagnisk świadczy ponadto częste występowanie poziomów wzbogacenia w związki żelaza i w ił, które wytrącały się na granicy strefy saturacji i aeracji. Poziomy te mają zazwyczaj miąższość rzędu $5 \mathrm{~cm}$. Melioracja przyczyniła się miejscami do znacznego zwietrzenia gytii i torfów. Gytie utraciły swą pierwotną strukturę i przybrały intensywny ceglasty kolor.

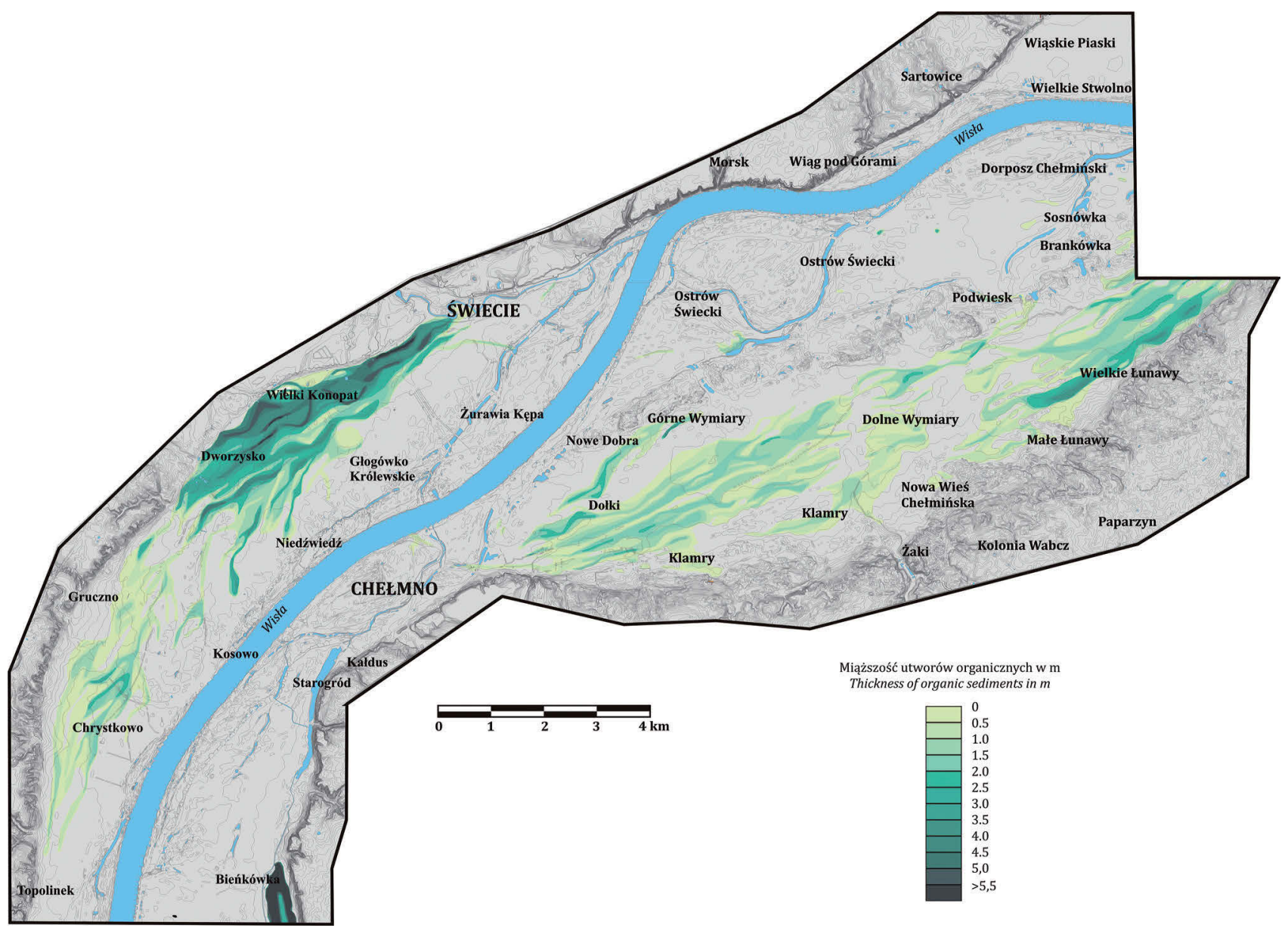

Ryc. 7. Zasięg i miąższość osadów i utworów organicznych w dnie doliny Wisły w okolicy Świecia

Fig. 7. Extent and thickness of the organic deposits on the area of the Vistula floodplain in the vicinity of Świecie 
W Dolinie Dolnej Wisły występuje silnie zaznaczony gradient zawartości węglanów w osadach biogenicznych i powodziowych. Osady te znajdują się bowiem w dużej ilości w dystalnych partiach dna doliny (gytie węglanowe), a w małej ilości lub prawie wcale na obszarach przykorytowych. Badania nad zawartością węglanów w suchej pozostałości (po odparowaniu próbek wody z Wisły, starorzeczy i kilku dopływów w Kotlinie Grudziądzkiej
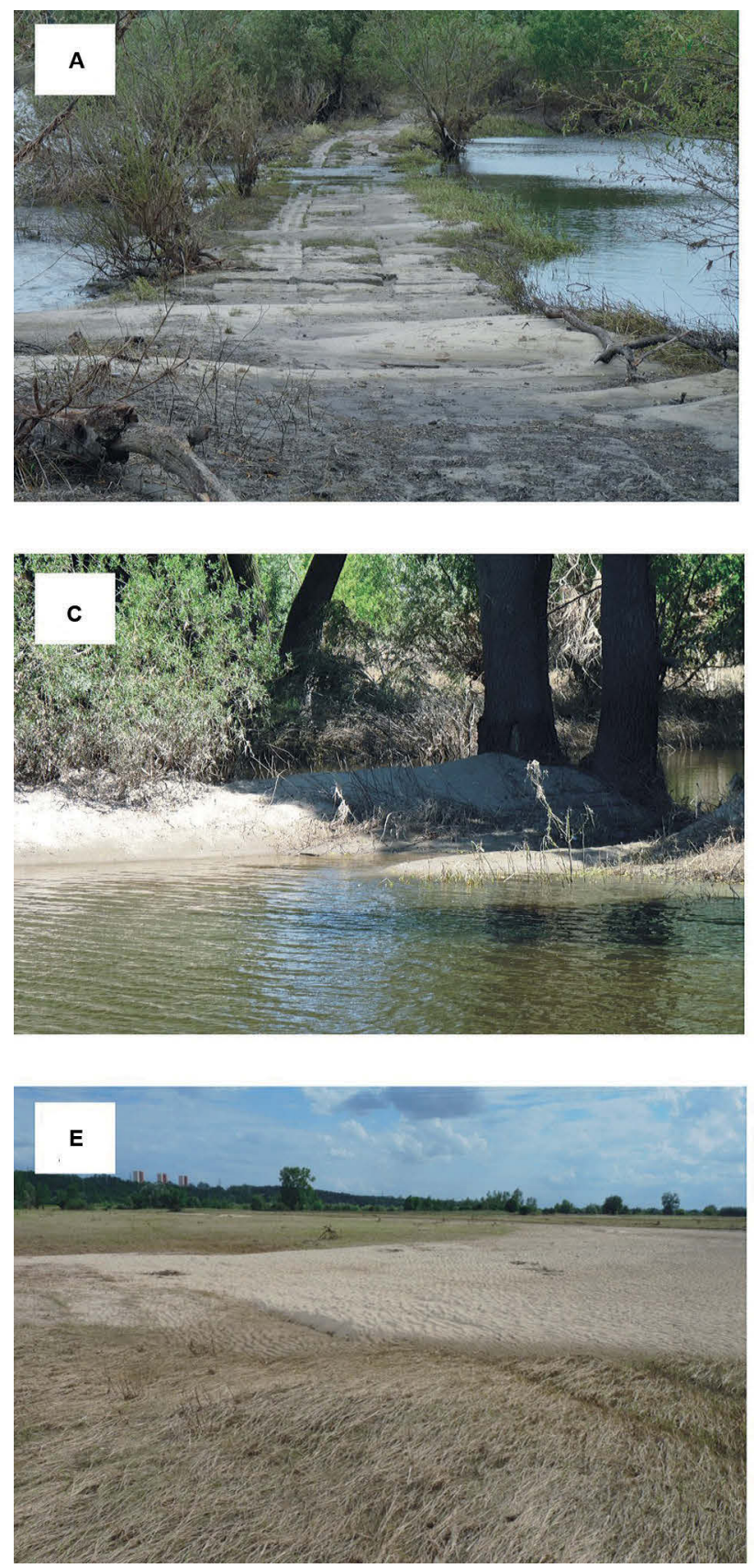

i Basenie Świeckim) wykazały, że ich zawartość w wodach powierzchniowych blisko koryta Wisły jest dwa razy mniejsza niż w dopływach (ryc. 9). W przykorytowej części równiny zalewowej następuje najprawdopodobniej rozpuszczanie węglanów i ich wynoszenie z wodami Wisły. Osady węglanowe zdeponowane w dystalnych fragmentach dna doliny składają się głównie z formy amorficznej, nieskrystalizowanej, która stanowi 67,5-98,6\%
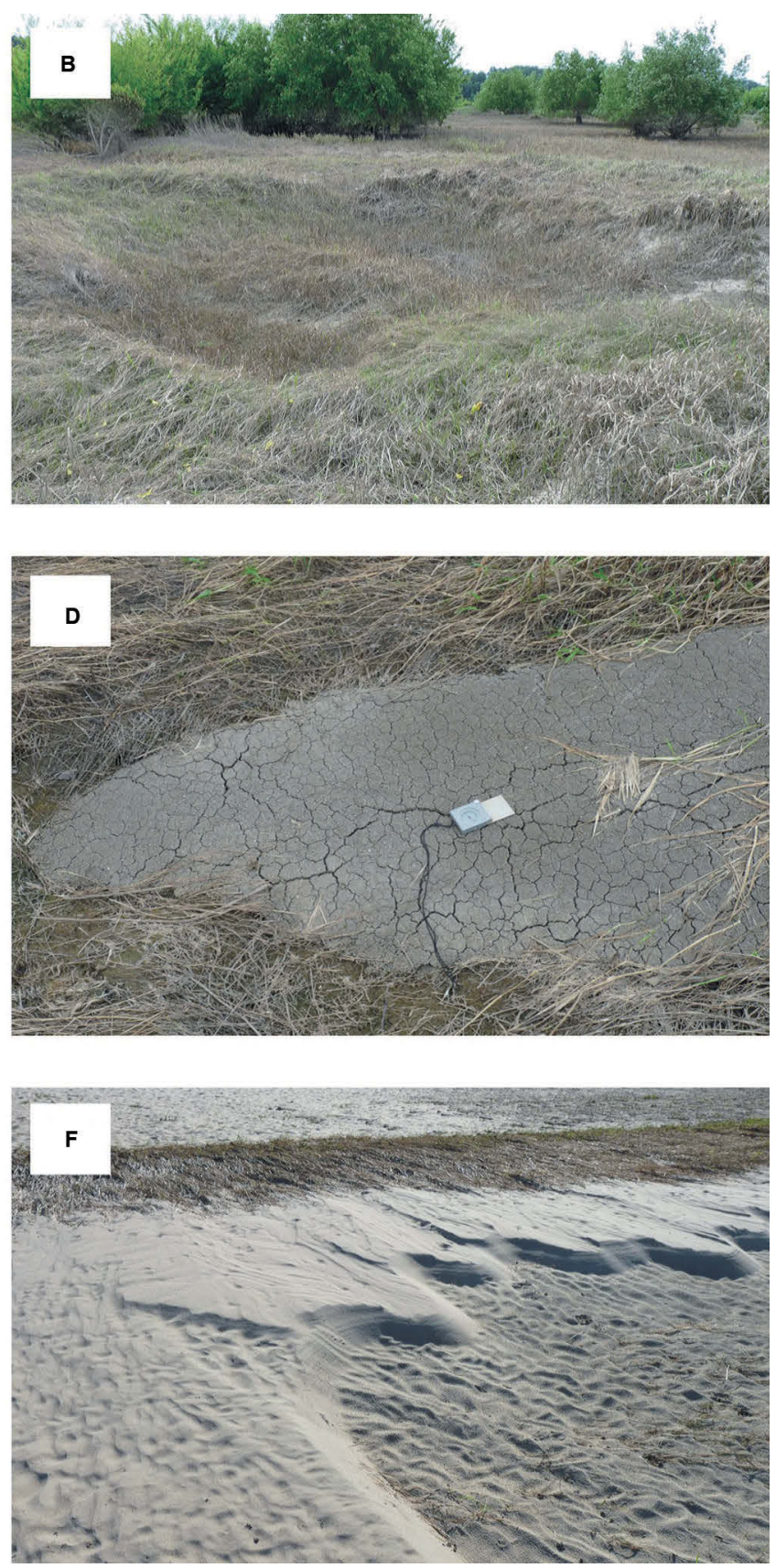

Ryc. 8. Formy i osady powstałe w czasie powodzi w maju 2010 w otoczeniu Starej Wisły w Bratwinie

A - piaszczyste formy akumulacyjne na przegrodzie kamiennej między północną i południową częścią starorzecza Starej Wisły, B - jama wirowa średnicy około $10 \mathrm{~m}$ i głębokości $1,5 \mathrm{~m}, \mathrm{C}$ - cienie piaszczyste za pniami drzew porastającymi brzegi starorzecza, D - odsyp zbudowany z fragmentów pokruszonego mułku, E - piaszczyste riplemarki uformowane podczas przepływu powodziowego, F - wstęga piaszczysta rozwinięta w pobliżu jeziora Starej Wisły, na powierzchni widoczne niewielkie riplemarki

Fig. 8. Forms and deposits developed as a results of the flood from May 2010 in the vicinity of Old Vistula in Bratwin

A - sandy deposition over stony groin between southern and northern parts of the fluvial lake, B - eddy erosion hole with a diameter of about $10 \mathrm{~m}$ and depth of 1,5, C - sandy shadows behind trees on the banks of the fluvial lake, D - bar formed from silt chips, E - sandy ripple marks formed during the flood, F - sandy ribbon developed in the vicinity of Old Vistula lake, on the surface small ripple marks visible 

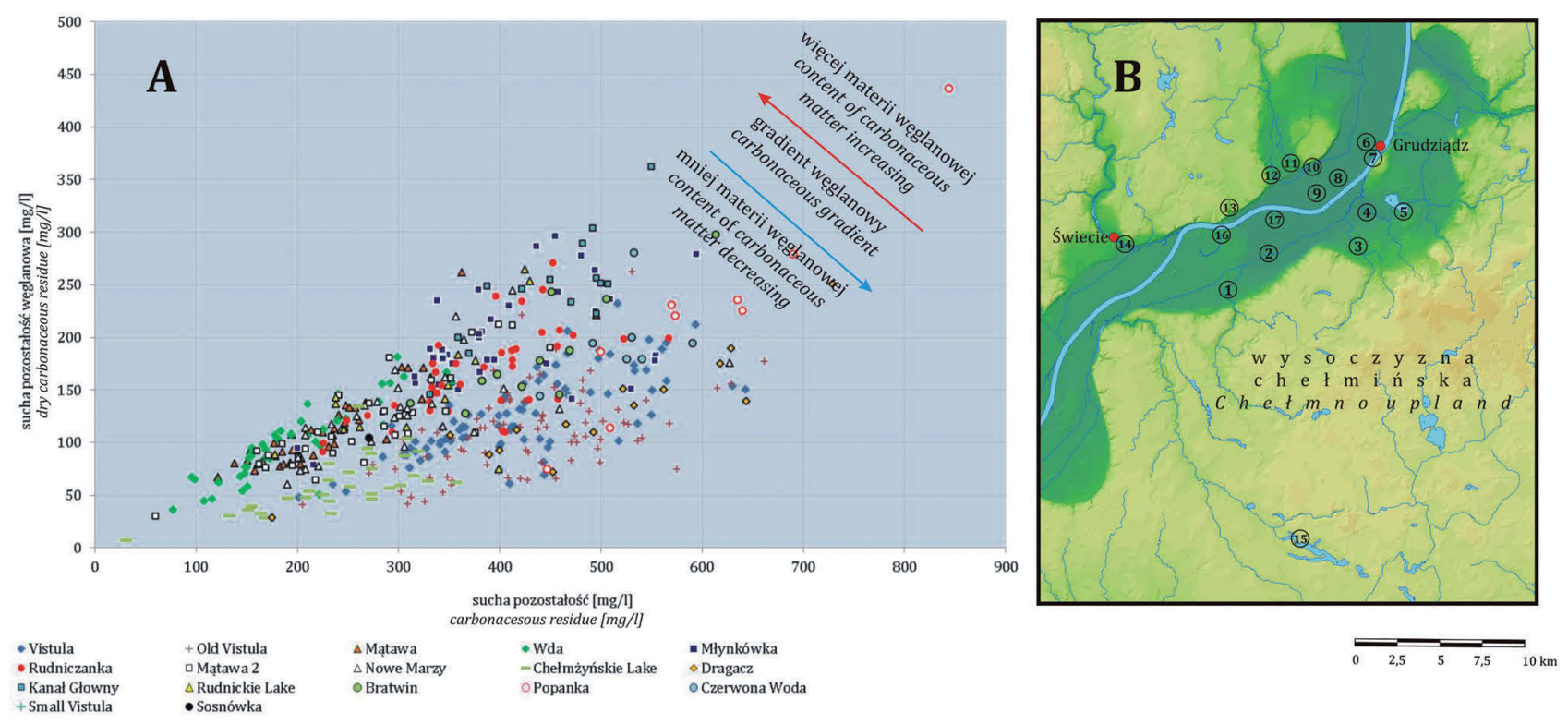

Ryc. 9. Zależność między całkowitą ilością materii rozpuszczonej i ilością rozpuszczonej materii węglanowej dla Wisły i Starej Wisły w Bratwinie (A) oraz lokalizacja punktów pomiarowych ilości zawiesiny i materii rozpuszczonej (B)

1 - Popanka, 2 - Kanał Główny, 3 - Młynkówka, 4 - Rudniczanka, 5 - Jezioro Rudnickie, 6 - Dragacz, 7 - Wisła, 8 - Stara Wisła, 9 - Bratwin, 10 Mątawa 2, 11 - Nowe Marzy, 12 - Mątawa, 13 - Czerwona Woda, 14 - Wda, 15 - Jezioro Chełmżyńskie, 16 - Mała Wisła, 17 - Sosnówka

Fig. 9. Relationship between the total amount of dissolved matter and dissolved carbonaceous matter for Vistula and Old Vistula in Bratwin (A) and location of measured sites (B)

1 - Popanka, 2 - Kanał Główny, 3 - Młynkówka, 4 - Rudniczanka, 5 - Rudnickie Lake, 6 - Dragacz, 7 - Vistula, 8 - Old Vistula, 9 - Bratwin, 10 - Mątawa 2, 11 - Nowe Marzy, 12 - Mątawa, 13 - Czerwona Woda, 14 - Wda, 15 - Chełmżyńskie Lake, 16 - Small Vistula, 17 - Sosnówka

masy osadów węglanowych (Bartkowiak 2008). Forma amorficzna węglanów łatwo wytrącająca się z roztworów i równie łatwo do nich wraca.

\section{Współczesne procesy morfogenetyczne ksztaltujące równinę zalewową}

Analiza dostępnych źródeł archiwalnych, w tym badań archeologicznych i paleogeograficznych, skłania do postawienia pytania, dlaczego w dnie Doliny Dolnej Wisły jeziora starorzeczne ulegają tylko częściowemu wypełnieniu i pozostają stabilne, czasami w skali tysięcy lat? Przykładem takiego jeziora jest Jezioro Starogrodzkie koło Chełmna, którego niewielki stopień wypełnienia przez 2400 lat dokumentują wyniki datowania radiowęglowego i badań palinologicznych prowadzonych przez Noryśkiewicz (2004). Na podstawie badań archeologicznych wiadomo, że jeziora rzeczne w okresie wczesnego średniowiecza mogły być wykorzystywane przez tutejszych mieszkańców jako szlaki transportowe (Bienias 2004). W wielu z tych jezior musiał istnieć wydajny mechanizm usuwania osadów dennych polegający głównie na ich „wyprzątaniu” w czasie przechodzenia katastrofalnych powodzi. Po regulacji Wisły i budowie wałów przeciwpowodziowych część nowo powstałych starorzeczy uległa wypełnieniu, ale proces ten wygasł mniej więcej w połowie XX w., na co wskazują wyniki analizy map historycznych. Na obszarze równiny zalewowej ukształtował się nowy stan równowagi między procesami erozji i sedymentacji. Niezależnie od tego regulacja koryta Wisły przyspieszyła tempo jego wcinania, które, zdaniem Andrzejewskiego (1994), znacznie zmalało w czasie od schyłku późnego vistulianu i w holocenie. Dowodem na to było obniżanie stropu litofacji bruku korytowego, stopniowe zwiększanie się miąższości przerabianych aluwiów oraz zmniejszenie przepływu i natężenia transportu rumowiska dennego w dopływach dolnej Wisły.

\section{Przekształcenia koryta Wisły w czasach historycznych}

Analiza zmian układu koryta Wisły w ciągu ostatnich 200 lat została opracowana na podstawie map Schröttera z początku XIX w. (ryc. 2A), zaś rekonstrukcję zamulania koryta Starej Wisły w okolicy Bratwina wykonano w odstępach czasowych około 100 lat, to jest na początku XIX, XX i XXI w. (ryc. 2B, C, D). Wyniki przeprowadzonych badań wskazują na to, że przed regulacją koryto Wisły było dwu- lub trzykrotnie szersze niż obecnie (do 1500 m szerokości), z licznymi, dużymi, osiągającymi szerokość dzisiejszego koryta rzecznego wyspami ustalonymi zaroślami wierzby i innymi drzewami. Koryto miało przeważnie dwie lub trzy odnogi, przy czym jedna była dominująca, szersza i tam następował główny przepływ wody. Pozostałe odnogi były węższe z przepływem dużo mniejszym niż w ramieniu dominującym. Zdaniem autorów, Wisła przed regulacją koryta reprezentowała typ 
rozwinięcia rzeki anastomozującej, z jedną, dominującą odnogą prowadzącą główny nurt. Nurt ten miał sinusoidalny przebieg.

Regulacja przeprowadzona w XIX w., polegająca na zwężeniu koryta przez ostrogi i budowę przegród kamiennych, przyczyniła się do przekierowania całego przepływu w dominujące ramię rzeczne. Spowodowało to początkowo akumulację osadów w odciętych ramionach. Zwężenie przepływu przyczyniło się do wcięcia tej części koryta, która była zajęta przez główny nurt w tempie 1,05 $\mathrm{cm} \mathrm{a}^{-1}$ (wartość wyznaczona dla okolic Torunia od roku 1888) (Babiński 1992). W efekcie tego wcięcia obniżył się też poziom wody gruntowej i starorzecze Starej Wisły przyjęło kształt pokazany na rycinie 2D. Bez tego efektu, mimo regulacji, starorzecze to przypominałoby bardziej formę przedstawioną na rycinie $2 \mathrm{C}$.

Zabiegi hydrotechniczne wraz z budową wałów przeciwpowodziowych prowadzono głównie w latach 70 . XIX w. (Babiński 1984). Ich efektem sedymentologicznym było zmniejszenie średniej średnicy ziarna deponowanego osadu powodziowego. Poza obszarem wałów przykorytowych, gdzie styl sedymentacji zasadniczo się nie zmienił, dotychczas deponowane mułki piaszczyste zostały w dużej części pokryte mułkami ilastymi. Nastąpiło bowiem podniesienie się średniego poziomu fali powodziowej, jej spłaszczenie i wydłużenie czasu trwania. W efekcie erozja na granicy woda-osady powodziowe jest mniejsza i drobne cząstki mułkowe oraz ilaste nie są wynoszone tak intensywnie jak przy niższej fali. Jest też więcej czasu na ich depozycję (Heine, Pinter 2012).

\section{Mobilność materii zawieszonej i rozpuszczonej w starorzeczu Starej Wisły i korycie Wisły - implikacje sedymentologiczne i geomorfologiczne}

Celem badań mobilności materii zawieszonej i rozpuszczonej było wyjaśnienie braku zamulania dużej części starorzeczy pomimo budowy przegród i ostróg rzecznych. Badania te prowadzono w starorzeczach, jak również w korycie Wisły i jej lokalnych dopływach (ryc. 9B). Ich wyniki zilustrowane są na rycinach 9A oraz 10A i 10B. Z punktu widzenia procesów sedymentacji istotne jest to, że w czasie wysokich stanów wody występuje różnica między ilością zawiesiny na korzyść głównego koryta Wisły w porównaniu z jej zawartością w starorzeczach. W okresie bardzo niskich stanów ilość zawiesiny może być w nich z kolei większa niż w korycie Wisły.

Obserwacje dokonywane w czasie regularnych pomiarów w starorzeczu Starej Wisły oraz wcześniejsze badania geomorfologiczne (zwłaszcza po przejściu potrójnej fali powodziowej w 2010 r.) pozwalają stwierdzić, że przebieg procesów transportu zawiesiny w czasie większych powodzi i wezbrań jest uzależniony od wielkości dostawy osadów w postaci zawieszonej z obszaru całej zlewni. Ponadto jest on uwarunkowany tempem dostawy materiału wraz z wodami powodziowymi wskutek transportu przydennego okruchów mułkowo-ilastych (trakcji) oraz erozji wirowej (ryc. 8B). W czasie niskich i średnich stanów niemniej istotnym czynnikiem staje się resuspensja osadów wywołana działaniem wiatru. Silne nawodnienie

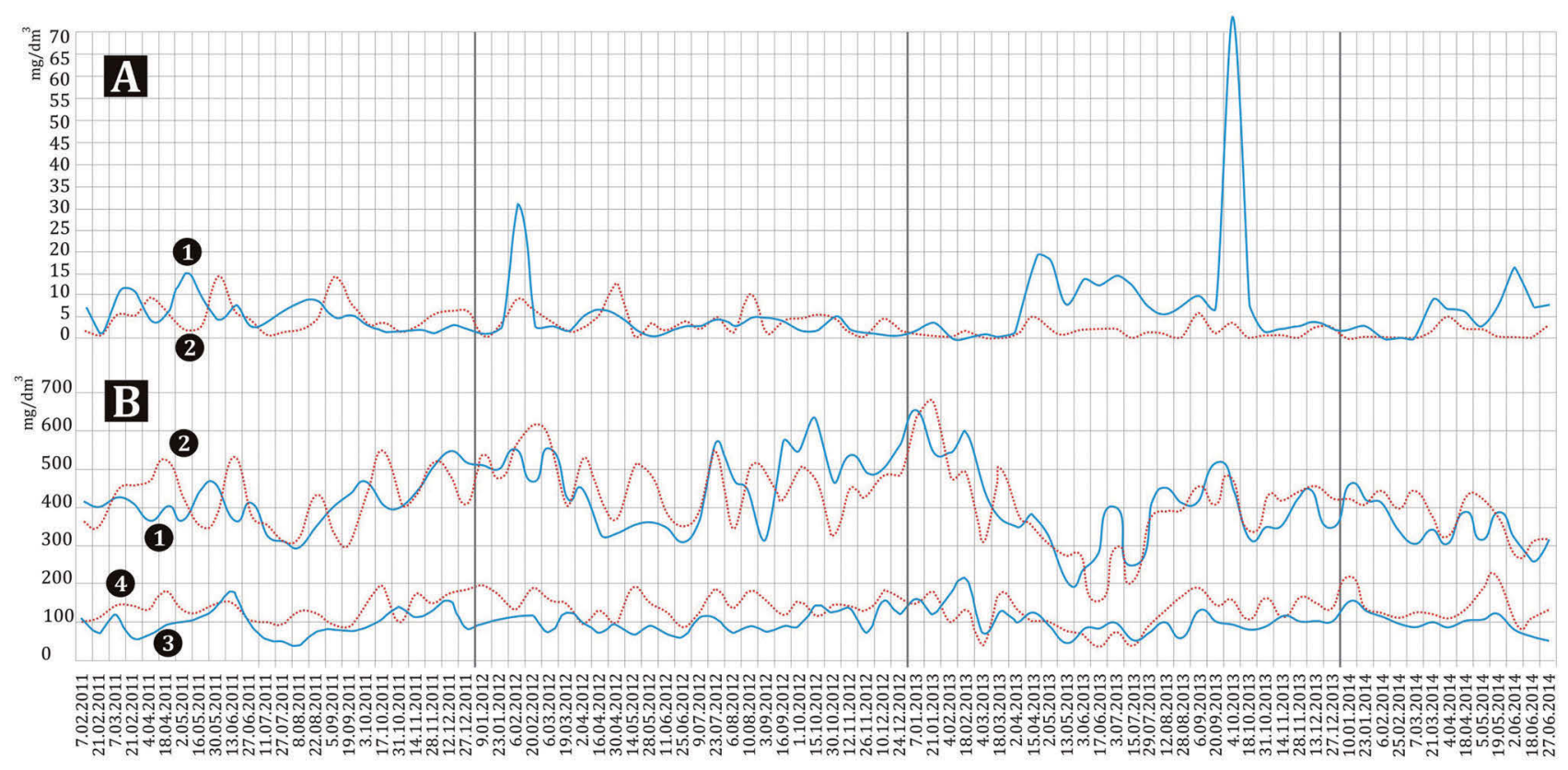

Ryc. 10. Ilość zawiesiny (A) oraz ilość materii rozpuszczonej (B) w korycie Wisły i Starej Wisły za okres 7.02.2011-27.06.2014.

A: 1 - Wisła, 2 - Stara Wisła; B: 1 - sucha pozostałość dla Wisły, 2 - sucha pozostałość dla Starej Wisły, 3 - sucha pozostałość węglanowa dla Wisły, 4 - sucha pozostałość węglanowa dla Starej Wisły

Fig. 10. The amount of the suspended matter (A) and dissolved matter (B) in the Vistula main channel and Old Vistula lake for the period 7.02.2011-27.06.2014

A: 1 - Vistula, 2 - Old Vistula; B: dry residue for Vistula, 2 - dry residue for Old Vistula, 3 - carbonaceous dry residue for Vistula, 4 - carbonaceous dry residue for Old Vistula 
osadów powodziowych powoduje ich niekohezyjność, a więc bardzo dużą podatność na erozję lub na działalność falowania (Chikita 1990).

Opierając się na obserwacjach terenowych, można stwierdzić, że osady dna starorzecza Starej Wisły, oprócz największych zagłębień jam wirowych o głębokości $7 \mathrm{~m}$, ulegają w okresie niskich stanów wody co najmniej kilkakrotnej resuspensji w cyklu rocznym (ryc. 10A). Proces ten może dokonywać się nawet w największych zagłębieniach wskutek działania prądów wirowych, a podczas większych wezbrań i powodzi - także w wyniku działania prądów gęstościowych (tzw. river plumes).

\section{Dyskusja}

Ukształtowanie dna doliny Wisły wskazuje na wyraźne uwarunkowania glacjalne wpływające na rozwój rzeźby fluwialnej (por. Kordowski 2014). Rozpoznanie morfologii spągu osadów powodziowych i biogenicznych (ryc. 3-7) wskazuje wyraźnie na obecność układu roztokowego dawnych koryt w okresie późnego glacjału (por. Weckwerth 2010, 2013).

Wyniki badań sedymentologicznych osadów powodziowych Wisły na odcinku od Górska do Grudziądza dowodzą, że w czasie ich depozycji (od przynajmniej 3400 lat temu, Kordowski 2007) pozycja koryta Wisły była stabilna, bowiem stwierdzono tylko jedną generację wałów przykorytowych. Wały te są niewielkie, a ich morfologia i budowa geologiczna wskazują na małą różnicę prędkości wód płynących w korycie i na równinie zalewowej w czasie powodzi. Z kolei do form dobrze rozwiniętych należą wstęgi piaszczyste. Osiągają one rozmiary do 1,5 km długości i 500-600 m szerokości (Kordowski 2007). Osady większości wstęg piaszczystych deponowane były w czasie zimowych powodzi zatorowych. Wykazują one największą średnicę ziaren ze wszystkich analizowanych osadów powodziowych, co oznacza niejednokrotnie katastrofalny charakter ich depozycji. Istotne zmiany położenia koryta Wisły w ciągu ostatnich trzech tysiącleci wyklucza także zmienność tekstualna basenów popowodziowych, gdzie grubsze ziarna mułkowe stwierdzono w przykorytowej części równiny zalewowej, zaś drobniejsze, mułkowo-ilaste, w jej części dystalnej. Analiza wykształcenia utworów biogenicznych prowadzi do wniosku, że są one głównie pochodzenia jeziornego. Sedymentacji powodziowej towarzyszyła zatem bardzo zmienna przestrzennie i czasowo sedymentacja limniczna. Skład chemiczny gytii w dolinie Wisły zależy od położenia w obrębie dna tej doliny. Istnieje bowiem wyraźna różnica ilości transportowanej rozpuszczonej materii węglanowej między dopływami Wisły (duży udział materii węglanowej) a samą Wisłą (mały udział). W dystalnych częściach dna doliny powoduje to wytrącanie się gytii węglanowych, natomiast w częściach proksymalnych doprowadza do rozpuszczania osadów węglanowych i wynoszenia ich wraz z wodami Wisły.
Analiza przestrzenna pokrywy osadów pozakorytowych pozwala krytycznie spojrzeć na pogląd występowania dwu serii mad w Dolinie Dolnej Wisły (Falkowski 1971, Myślińska 1980, 2001, Drozdowski 1982, Myślińska i in. 1982). Niewątpliwie takie zróżnicowanie istnieje i jest związane $\mathrm{z}$ naturalną ewolucją mad w warunkach braku znacznej migracji koryta rzecznego. Związek rodzaju mad ze zmianami stylu rozwinięcia koryta rzecznego $\mathrm{z}$ roztokowego na meandrujący i z powrotem, w analizowanym odcinku doliny Wisły, nie jest udowodniony. Grubienie ziarna w górę profilu pokrywy madowej należy wiązać z tym, że sukcesywnie nadbudowywana równina zalewowa podnosi się i każda następna powódź, by wprowadzić na nią nowy materiał osadowy, musi mieć większą amplitudę. Zatem $\mathrm{z}$ biegiem czasu w zapisie kopalnym zaznaczają się coraz częściej powodzie, które są w stanie przynieść grubsze ziarno.

Wyniki analizy zmian sposobu rozwinięcia koryta Wisły dowodzą istnienia układu roztokowego jej koryta w okresie późnego glacjału. W czasie ostatnich 3 tys. lat Wisła była $\mathrm{z}$ kolei w początkowym stadium anastomozowania, na co wskazuje zróżnicowanie rozmieszczenia i typów osadów powodziowych. Do podobnych wniosków prowadzi zestawienie archiwalnych materiałów kartograficznych za ostatnie 200 lat. Kwestią dyskusyjną pozostaje rozstrzygnięcie stylu rozwinięcia rzeki w okresie od początku holocenu do około 3 tys. lat wstecz, kiedy to rozpoczęła się depozycja mad. Opierając się na wynikach datowań osadów biogenicznych z Basenu Unisławskiego wiadomo, że utwory biogeniczne były deponowane w dolinie Wisły już od początku holocenu (Niewiarowski 1987). W dystalnych częściach równiny zalewowej nie ma w nich wkładek osadów piaszczystych ani mułkowych, których pochodzenie można by wiązać z oddziaływaniem rzeki. W dystalnych fragmentach dna doliny Wisły nie uległy rozmyciu także stożki późnoglacjalnych spływów gliniastych (por. Kordowski 2014), co również wskazuje na ograniczone możliwości zmian pozycji koryta w okresie holocenu. $Z$ tego względu uprawnione wydaje się przyjęcie tezy o stabilności koryta Wisły w całym holocenie. Meandrowanie Wisły, postulowane przez Berglunda i Drozdowskiego (1976), jak na razie, nie znajduje potwierdzenia, nie stwierdzono bowiem charakterystycznych wałów i bruzd po przyrastaniu łach meandrowych. Rozwinięcie koryta mogło zatem być albo proste, o małej krętości, albo takie, jak w ciągu ostatnich 3 tys. lat, a więc słabo anostomozujące. Rozstrzygnięcie tego problemu wymaga dalszych badań.

Zagadnienie stylu rozwinięcia i ewentualnej migracji koryta rzeki ma istotne znaczenie dla wytłumaczenia długowieczności niektórych starorzeczy, powstałych zarówno przed regulacją koryta Wisły, jak i po niej. Jego układ anastomozujący jest pod tym względem predystynowany do długotrwałego przetrwania koryt rzecznych i starorzeczy (Smith, Smith 1980). W opinii autorów, ich zachowaniu sprzyja przede wszystkim współdziałanie wynoszenia osadów z wodami powodziowymi, wezbraniowymi lub z wodami gruntowymi utrzymującymi 
pewien minimalny stan wody konieczny do istnienia odpływu (łączności hydraulicznej) ze starorzecza do koryta głównego. Wynoszenie to następuje na skutek erozji osadów na granicy woda/osad w efekcie trakcji oraz powstawania wirów wód wezbraniowych. W czasie niskich stanów wody istotną rolę spełnia resuspensja wiatrowa. Podobne efekty morfologiczne i sedymentologiczne erozji wirowej zostały opisane w dolinie Odry z okresu powodzi w 1997 r. (Kurowski 1998). W przypadku wielu starorzeczy sumaryczny bilans wynoszenia i depozycji osadów na przestrzeni stuleci i tysiącleci może być zbliżony do zera przy jednocześnie postępującym procesie nadbudowywania równiny zalewowej między przetrwałymi starorzeczami. Długi okres istnienia starorzeczy w proksymalnych częściach równin zalewowych zdaje się permanentną cechą anastomozujących systemów rzecznych, w których zaznacza się brak znacznych lateralnych przemieszczeń koryta (Smith, Smith 1980, Makaske 1998, 2001, Makaske i in. 2002). W konsekwencji tego procesu wody powodziowe przemieszczają się przez całe stulecia, a nawet tysiąclecia tymi samymi szlakami, przeważnie na linii dawnych koryt i ramion bocznych wynosząc nagromadzony w nich osad. Takim systemem, chociaż w początkowym stadium rozwoju, dodatkowo zakłóconym w ciągu ostatnich 200 lat regulacjami hydrotechnicznymi, jest też system fluwialny dolnej Wisły (Kordowski 2009b).

W przypadku regionu dolnej Wisły anastomozowanie jej koryta mogło być stymulowane prawdopodobnie obecnością kotlin i basenów dolinnych, uformowanych jeszcze przed nasunięciem ostatniego lądolodu, w miejscu krzyżowania się starszych, kopalnych dolin. Odgrywały one rolę podobną do obniżeń przedgórskich sprzyjających powstawaniu klasycznych systemów anastomozujących (por. Smith, Smith 1980, Rust 1981, Miall 1996, Makaske 1998, Makaske i in. 2002, Wang i in. 2002). Istotne znaczenie miało też szybkie ustabilizowanie się systemu teras, którego ukształtowanie nastąpiło już przed allerødem (Berglund, Drozdowski 1976). Po tym czasie modelowana była tylko współczesna równina zalewowa wraz $\mathrm{z}$ równinami biogenicznymi, polami wydmowymi oraz formami i osadami stokowymi.

\section{Wnioski}

Rozwój procesów fluwialnych w Dolinie Dolnej Wisły pozostaje pod silnym wpływem morfogenezy glacjalnej północnej Polski. Koryto Wisły miało w późnym glacjale rozwinięcie roztokowe, w holocenie zaś układ prosty, o małej krętości lub słabo anastomozujacy, który w czasie narastania pokrywy madowej przekształcił się w typowo anastomozujący. Analiza zróżnicowania litologicznego i przestrzennego rozmieszczenia pokrywy madowej wskazuje na dużą stabilność koryta rzecznego przynajmniej w ciągu ostatnich 3 tys. lat. Główne, naturalne zmiany rzeźby równiny zalewowej zachodziły w okresie zimowych zatorów lodowych. Gradient pręd- kości wody, jaki występował w czasie epizodów powodziowych między korytem głównym rzeki a równiną zalewową, w przypadku Doliny Dolnej Wisły jest niewielki. Równina zalewowa dolnej Wisły charakteryzuje się dużą stabilnością starorzeczy i odpornością na zabiegi hydrotechniczne, co jest podstawową cechą systemów anastomozujących. Na depozycję osadów biogenicznych i limnicznych istotny wpływ ma zmienność ilości węglanów wchodzących w skład wód gruntowych, które tworzą gradient geochemiczny między korytem Wisły a dystalnymi obszarami dna doliny.

\section{Podziękowania}

Część materiałów do niniejszego opracowania zebrana została w trakcie realizacji grantów Ministerstwa Nauki i Szkolnictwa Wyższego nr NN 306289635 „Morfogeneza Kotliny Grudziądzkiej w świetle analizy osadów i rzeźby doliny Wisły oraz obszarów przyległych" oraz N N306 084837 „Kierunki przemian rzeźby i depozycji osadów w wielokorytowych systemach fluwialnych Wisły i Dunaju w warunkach zabudowy hydrotechnicznej - studium porównawcze". Kontynuacja prac była możliwa dzięki projektowi ICLEA (www.iclea.de). [This is a contribution to ICLEA (Virtual Institute for Integrated Climate and Landscape Evolution Analyses) of the Helmholtz Association]. Recenzentom i Redaktorom tomu dziękujemy za trud oceny i poprawy maszynopisu.

\section{Literatura}

Andrzejewski L., 1994. Ewolucja systemu fluwialnego doliny dolnej Wisły w późnym vistulianie i holocenie na podstawie wybranych dolin jej dopływów. Rozprawy UMK, Toruń.

Babiński Z., 1981. Wstępna charakterystyka morfologiczna dna koryta dolnej Wisły na odcinku Włocławek-Chełmno w świetle map i fotointerpretacji. Gospodarka Wodna 4-5: 105-109.

Babiński Z., 1984. The effects of human activity on changes in the lower Vistula channel. Geographia Polonica 50: 271-282.

Babiński Z., 1992. Współczesne procesy korytowe dolnej Wisły. Prace Geograficzne 157.

Bartkowiak A., 2008. Charakterystyka uprawnych gleb aluwialnych wytworzonych na martwicy wapiennej w Basenie Unisławskim. Maszynopis pracy doktorskiej. Uniwersytet Techniczno-Przyrodniczy, Wydział Rolniczy, Katedra Gleboznawstwa i Ochrony Gleb, Bydgoszcz.

Berglund B.E., Drozdowski E., 1976. Development and chronology of the lower Vistula river valley, North Poland. Boreas 5: 95-107.

Bienias D., 2004. Położenie fizjograficzne i chronologia stanowisk archeologicznych w Kałdusie i jego otoczeniu. W: W. Chudziak (red.), Wczesnośredniowieczny zespół osadniczy w Kałdusie. Studia przyrodniczo-archeologiczne. Mons Sancti Laurenti 2: 281-298.

Biernacki Z., 1968. Wiek oraz przebieg przyrostu miąższości mad na tarasie zalewowym Wisły w rejonie Warszawy w świetle stanowisk archeologicznych. Przegląd Geologiczny 16(1): 13-20.

Biernacki Z., 1975. Holocene and Late Pleistocene alluvial sediments of the Vistula River near Warsaw. Biuletyn Geologiczny 19: 199-217.

Bloom A.L, 1982. Powierzchnia Ziemi. Państwowe Wydawnictwo Naukowe, Warszawa.

Błaszkiewicz M., 1998. Dolina Wierzycy, jej geneza oraz rozwój w późnym plejstocenie i holocenie. Dokumentacja Geograficzna 10, IGiPZ PAN, Warszawa.

Błaszkiewicz M., 2005. Późnoglacjalna i holoceńska ewolucja obniżeń jeziornych na Pojezierzu Kociewskim (wschodnia część Pomorza). Prace Geograficzne 201. 
Bridge J.S., 1984. Large scale facies sequences in alluvial overbank sediments. Journal of Sedimentary Research 54(2): 583-588.

Bridge J.S., 2003. Rivers and Floodplains. Forms, Processes, and Sedimentary Record. Blackwell Publishing.

Bridge J.S., 2006. Fluvial facies models: Recent development. Special Publications of International Association of Sedimentologists 84: 85-170.

Brykczyński M., 1986. O głównych kierunkach rozwoju sieci rzecznej Niżu Polskiego w czwartorzędzie. Przegląd Geograficzny 57(3): 411-440.

Chikita K., 1990. Sedimentation by river-induced turbidity currents: field measurements and interpretation. Sedimentology 37: 891-905.

Davies R.A. Jr., 1983. Depositional Systems. A Genetic Approach to Sedimentary Geology. Prentice Hall, Inc. Englewood Cliffs, New Jersey.

Drozdowski E., 1974. Geneza Basenu Grudziądzkiego w świetle osadów i form glacjalnych. Prace Geograficzne 104.

Drozdowski E., 1979. Deglacjacja dolnego Powiśla w środkowym würmie i związane z nią środowiska depozycji osadów. Prace Geograficzne 132

Drozdowski E., 1982. The evolution of the lower Vistula river valley between the Chełmno Basin and the Grudziadz Basin. W: L. Starkel (red.), Evolution of the Vistula river valley during the last 15000 years. Geographical Studies, Special Issue 1: 131-147.

Falkowski E., 1971. Historia i prognoza rozwoju koryta wybranych odcinków rzek nizinnych Polski. Biuletyn Geologiczny 12: 5-122.

Falkowski E., 1980. Problemy genezy i interpretacji doliny środkowej i dolnej Wisły. Przegląd Geologiczny 32(6): 345-347.

Falkowski E., 1990. Morphogenetic classification of river valleys developing in formerly glaciated areas for the needs of mathematical and physical modelling in hydrotechnical projects. Geographia Polonica 58: 53-67.

Galon R., 1934. Dolina dolnej Wisły, jej kształt i rozwój na tle budowy dolnego Powiśla. Badania Geograficzne Polski Północno-Zachodniej $12-13$.

Galon R., 1953. Morfologia sandru i doliny Brdy. Studia Societatis Scientarum Torunensis 1(6).

Galon R., 1961. Morphology of the Noteć-Warta (or Torun-Eberswalde) ice marginal streamway. Prace Geograficzne 29.

Gibling M.R., Rust B.R., 1984. Channel margins in Pennsylvanian braided fluvial deposit: the Morien Group near Sydney, Nova Scotia, Canada. Journal of Sedimentary Petrology 54(3): 773-782.

Gierszewski P., Szmańda J.B., 2012. Geomorphological and sedimentological effects of failure of the Vistula flood embankment near Płock 12. Mezinárodna konference, Stav geomorfologických výskumů v roce 2012, Geomorfologický Sborník 10, 18. â 20.04.2012 Parkhotel Sokolov, Czech Republic: 9-10.

Grześ M., 1985. Problemy zatorów lodowych i powodzi zatorowych na dolnej Wiśle. Przegląd Geograficzny 57(4): 499-525.

Grześ M., 1991. Zatory i powodzie zatorowe na dolnej Wiśle, mechanizmy i warunki. IGiPZ PAN, Warszawa.

Happ S.C., Rittenhouse G., Dobson G.C., 1940. Some Principles of Accelerated Stream and Valley Deposition. U.S. Department of Agriculture, Technical Bulletin 695: 22-31.

Heine R.A., Pinter N., 2012. Levee effects upon flood levels: an empirical assessment. Hydrological Processes 26: 3225-3240.

Kalicki T., 2000. Grain size of the overbank deposits as carriers of paleogeographical information. Quaternary International 72: 107-114.

Koc L., 1972. Zmiany koryta Wisły w XIX i XX wieku między Płockiem i Toruniem. Przegląd Geograficzny 44(4): 703-719.

Kordowski J., 1999. Litologia osadów pozakorytowych Wisły w zachodniej części Kotliny Toruńskiej. Przegląd Geologiczny 47(3): 273-279

Kordowski J., 2001. Litologiczne i genetyczne zróżnicowanie osadów pozakorytowych równiny zalewowej Wisły między Górskiem i Chełmnem. Przegląd Geograficzny 73(3): 351-369.

Kordowski J., 2004. Osady i rzeźba doliny Wisły w okolicach Chełmna i Świecia. W: W. Chudziak (red.), Wczesnośredniowieczny zespół osadniczy w Kałdusie. Studia przyrodniczo-archeologiczne. UMK, Toruń. Mons Sancti Laurentii 2: 43-68.
Kordowski J., 2005. Problemy interpretacji rzeźby dna doliny dolnej Wisły w Basenie Świeckim w świetle ostatnich badań geomorfologicznych. Przegląd Geograficzny 77(3): 343-355.

Kordowski J., 2007. Morfologia, struktury sedymentacyjne i geneza wstęg piaszczystych równiny zalewowej dolnej Wisły między Górskiem i Szynychem. Przegląd Geologiczny 55(9): 785-794.

Kordowski J., 2009a. Some remarks about the Lower Vistula valley development in the light of geomorphological and sedimentological investigations (with special regard to the floodplain). Polish Geological Institute Special Papers 25: 21-36.

Kordowski J., 2009b. Litofacjalna charakterystyka osadów równiny zalewowej Wisły - stanowisko Kosowo, Basen Unisławski. W: M. Pisarska-Jamroży, Z. Babiński (red.), Plejstoceńskie środowiska sedymentacyjne Pojezierza Pomorskiego. Wydawnictwo UKW, Bydgoszcz: 108-116.

Kordowski J., 2013. The role of blocks of dead ice in the deposition of late glacial sediments in a large valley: A case study from the Vistula river valley in the Grudziadz Basin, north Poland. Geographia Polonica 86(4): 341-361.

Kordowski J., 2014. Rola brył martwego lodu w morfogenezie doliny fordońskiej - formy rzeźby i osady. Landform Analysis 25.

Kordowski J., Tyszkowski S., Bienias D., 2012. Budowa geologiczna i przekształcenia Góry Zamkowej i jej otoczenia. W: M. Wiewióra (red.), Zamek w Grudziądzu. Studia i materiały. Wydawnictwo Naukowe Uniwersytetu Mikołaja Kopernika, Toruń: 29-47.

Kurowski L., 1998. Erozyjna działalność wód schyłkowego stadium powodzi na podstawie form utworzonych w lipcu 1997 r. na terenie parku w Koźlu. Przegląd Geologiczny 46(11): 1179-1185.

Legros J.-P., 2012. Major Soil Groups of the World Ecology, Genesis, Properties and Classification. Taylor \& Francis Group, LLC, Boca Raton.

Ludwikowska-Kędzia M., 2000. Ewolucja środkowego odcinka doliny rzeki Belnianki w późnym glacjale i holocenie. Wydawnictwo Akademickie Dialog, Warszawa.

Makkavejev N.I., Čal'ov R.S., 1986. Rusl'ovye procesy. Izdatelstvo Moskovskogo Universiteta, Moskva.

Makaske B., 1998. Anastomosing rivers: Forms, processes and sediments. Netherlands Geographical Studies 249

Makaske B., 2001. Anastomosing rivers: a review of their classification, origin, and sedimentary products. Earth-Science Reviews 53: 149-196.

Makaske B., Smith D.G., Berendsen H.J.A., 2002. Avulsions, channel evolution and floodplain sedimentation rates of the anastamosing upper Columbia River, British Columbia, Canada. Sedimentology 49: 1049-1071.

Miall A.D., 1996. The geology of fluvial deposits. Sedimentary facies, basin analysis and petroleum geology. John Wiley and Sons, Springer Verlag, Berlin-Heidelberg-New York.

Mjøs R., Walderhaug J., Prestholm E., 1993. Crevasse splay sandstone geometries in the Middle Jurasic Ravenscar Group of Yorkshire, UK. Special Publications of International Association of Sedimentologists 17: $167-184$

Myślińska E., 1980. Inżyniersko-geologiczna charakterystyka mad doliny Wisły. Przegląd Geologiczny 28(6): 348-351.

Myślińska E., 2001. Grunty organiczne i laboratoryjne metody ich badania. Wydawnictwo Naukowe PWN, Warszawa.

Myślińska E., Hoffman E., Kulesza-Wiewióra K., 1982. Zróżnicowanie litologiczne mad w wybranych odcinkach doliny Wisły. Przegląd Geologiczny 30(9): 474-479.

Nanson G.C., Croke J.C., 1992. A genetic classification of floodplains. Geomorphology 4: 459-486.

Niewiarowski W., 1968. Morfologia i rozwój pradoliny i doliny dolnej Drwęcy. Studia Societatis ScientarumTorunensis 6(6).

Niewiarowski W., 1987. Evolution of the lower Vistula valley in the Unisław Basin and the river gap to the North of Bydgoszcz Fordon. W: L. Starkel (red.), Evolution of the Vistula River Valley during the last 15000 years. Geogr. Studies, Special Issue 4(2): 234-252.

Noryśkiewicz B., 2004. Badania palinologiczne osadów limnicznych jezior Starogrodzkich. W: W. Chudziak (red.), Wczesnośredniowieczny zespół osadniczy w Kałdusie. Studia przyrodniczo-archeologiczne. Mons Sancti Laurenti 2: 165-176. 
Prusinkiewicz Z., Bednarek R., 1991. Gleby. W: L. Starkel (red.), Geografia Polski, środowisko przyrodnicze. PWN, Warszawa: 387-412.

Reineck H.E., Singh I.B., 1986. Depositional Sedimentary Environments. Springer Verlag, New York-Heidelberg-Berlin.

Rust B.R., 1981. Sedimentation in an arid-zone anastomosing fluvial system. Journal of Sedimentary Research 51: 745-755.

Smith D.G., Smith N.D., 1980. Sedimentation in anastomosed river systems: examples from alluvial valleys near Banff, Alberta. Journal of Sedimentary Petrology 50(1): 157-164.

Szmańda J.B., 2000, Litodynamiczny zapis powodzi w aluwiach pozakorytowych Wisły. W: P. Molewski, W. Wysota (red.), Dawne i współczesne systemy morfogenetyczne środkowej części Polski Północnej. Przewodnik wycieczek terenowych. V Zjazd Geomorfologów Polskich, 11-14 września 2000, Toruń: 221-231.

Szmańda J.B., 2006. Rytmika powodziowa w aluwiach pozakorytowych Wisły, Drwęcy i Tążyny. W: P. Gierszewski, T.K. Karasiewicz (red.), Idee i praktyczny uniwersalizm geografii. Dokumentacja Geograficzna 32: 266-270.

Szmańda J.B., 2007. Porównanie interpretacji warunków transportu osadów na diagramie $\mathrm{C} / \mathrm{M}$ i analizy krzywych kumulacyjnych aluwiów pozakorytowych Wisły w Toruniu. W: E. Smolska, D. Giriat (red.), Rekonstrukcja dynamiki procesów geomorfologicznych - formy rzeźby i osady. Wydział Geografii i Studiów Regionalnych UW, Komitet Badań Czwartorzędu, Warszawa: 367-376.

Szmańda J.B., 2011. Zapis warunków depozycji w uziarnieniu aluwiów pozakorytowych. Landform Analysis 18.

Szmańda J.B., Gierszewski P., 2013. Sediments Trend Analysis (STA) in reconstruction of accumulation conditions of overbank deposits on the crevasse splay (Świniary, the Vistula river valley a case study). 13. Mezinárodna konference Stav geomorfologických výskumů v roce 2013, Geomorfologický Sborník 11, 24. â 26.04.2013 Mikulov, Czech Republic: 42-43.

Talling P.J., Masson D.G., Sumner E.J., Malgesini G., 2012. Subaqueous sediment density flows: Depositional processes and deposit types. Sedimentology 59: 1937-2003.
Tomczak A., 1982. The evolution of the Vistula river valley between Torun and Solec Kujawski during the Late Galcial and Holocene. W: L. Starkel (red.), Evolution of the Vistula river valley during the last 15000 years. Pt. I. Geographical Studies, Special Issue 1: 108-129.

Tomczak A., 1987. Evolution of the Vistula Valley in the Torun Basin in the Late Galcial and Holocene. W: L. Starkel (red.), Evolution of the Vistula River Valley during the last 15000 years. Geographical Studies, Special Issue 4(2): 207-231.

Wang S., Li J., Yin S., 2002. Basic characteristics and controlling factors of anastomosing fluvial systems. Chinese Geographical Science 10(1): 30-37.

Weckwerth P., 2006. Problem bifurkacji Wisły pod Fordonem (Bydgoszcz) na tle ewolucji Kotliny Toruńskiej pod koniec plenivistulianu. Przegląd Geograficzny 78(1): 47-68.

Weckwerth P., 2010. Evolution of the Torun Basin in the Late Weichselian. Landform Analysis 14: 57-84.

Weckwerth P., 2013. Ewolucja fluwialnych systemów depozycyjnych i jej uwarunkowania paleośrodowiskowe w Kotlinie Toruńskiej podczas zlodowacenia wisły. Wydawnictwo Naukowe Uniwersytetu Mikołaja Kopernika, Toruń.

Wolman M.G., Leopold L.B., 1957. Flood plains. U.S. Geological Survey, Professional Paper 282-B.

Wysota W., Lankauf K.R., Molewski P., Szmańda J., 1996. Sedymentologia interstadialnej serii rzecznej (Rzęczkowo) zlodowacenia wisły (vistulian) odsłoniętej w SW krawędzi Wysoczyzny Chełmińskiej. Acta Universitatis Nicolai Copernici, Geographia 28: 39-63.

Zieliński Z., 1995. Kod litofacjalny i litogenetyczny - konstrukcja i zastosowanie. W: E. Mycielska-Dowgiałło, J. Rutkowski (red.), Badania osadów czwartorzędowych: wybrane metody i interpretacja. Wydział Geografii i Studiów Regionalnych Uniwersytetu Warszawskiego, Państwowy Instytut Geologiczny, Komisja Litologii i Genezy Osadów Czwartorzędowych Komitetu Badań Czwartorzędu PAN, AKAPIT-DTP, Warszawa: 220-235.

Zwoliński Z., 1985. Sedymentacja osadów przyrostu pionowego na terasie zalewowej Parsęty. Badania Fizjograficzne nad Polską Zachodnią 35(A): 205-238. 